\title{
Modeling Atmospheric Deposition Using a Stochastic Transport Model
}

by

R. L. Buckley

Westinghouse Savannah River Company

Savannah River Site

Aiken, South Carolina 29808

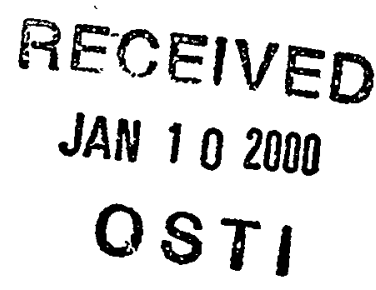

DOE Contract No. DE-AC09-96SR18500

This paper was prepared in connection with work done under the above contract number with the U.S. Department of Energy. By acceptance of this paper, the publisher and/or recipient acknowledges the U.S. Government's right to retain a nonexclusive, royalty-free license in and to any copyright covering this paper, along with the right to reproduce and to authorize others to reproduce all or part of the copyrighted paper. 


\title{
Modeling Atmospheric Deposition Using a Stochastic Transport Model (U)
}

\author{
Robert L. Buckley
}

Savannah River Technology Center

Publication Date: November 1999

Patent Status

This internal management report is being transmitted without DOE patent clearance, and no further dissemination or publication shall be made of the report without prior approval of the DOE-SR patent counsel.

\section{Westinghouse Savannah River Company Savannah River Site Aiken, SC 29808}

This document was prepared in connection with work done under Contract No. DE-AC09-96SR18500 with the U. S. Department of Energy 


\section{DISCLAMER}

This report was prepared as an account of work sponsored by an agency of the United States Government. Neither the United States Government nor any agency thereof, nor any of their employees, makes any warranty, express or implied, or assumes any legal liability or responsibility for the accuracy, completeness, or usefulness of any information, apparatus, product or process disclosed, or represents that its use would not infringe privately owned rights. Reference herein to any specific commercial product, process or service by trade name, trademark, manufacturer, or otherwise does not necessarily constitute or imply its endorsement, recommendation, or favoring by the United States Government or any agency thereof. The views and opinions of authors expressed herein do not necessarily state or reflect those of the United States Government or any agency thereof.

This report has been reproduced directly from the best available copy.

Available for sale to the public, in paper, from: U.S. Department of Commerce, National Technical Information Service, 5285 Port Royal Road, Springfield, VA 22161, phone: (800) 553-6847

fax: (703) 605-6900

email: orders@ntis.fedworld.gov

online ordering: http://www.ntis.gov/ordering.htm .

Available electronically at http://www.doe.gov/bridge

Available for a processing fee to U.S. Department of Energy and its contractors, in paper, from: U.S. Department of Energy, Office of Scientific and Technical Information, P.O. Box 62, Oak Ridge, TN 37831-0062, phone: (865) 576-8401

fax: (865) 576-5728

email: reports@adonis.osti.gov 


\section{DISCLAIMER}

Portions of this document may be illegible in electronic image products. Images are produced from the best available original document. 
WSRC-TR-99-00409

November 1999

DOCUMENT: $\quad$ WSRC-TR-99-00409

TITLE:

Modeling Atmospheric Deposition Using a Stochastic Transport

Model (U)

TASK:

TECHNICAL REVIEW

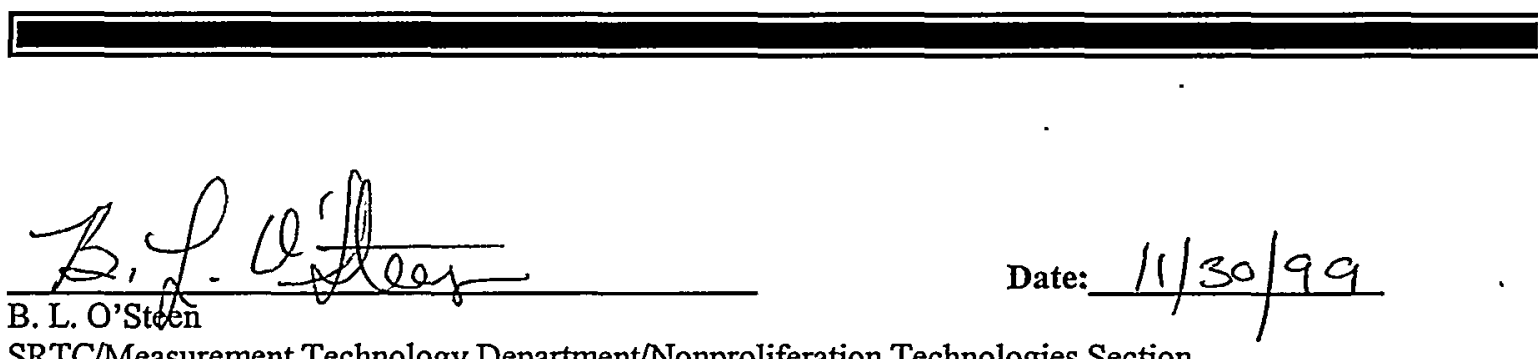

SRTC/Measurement Technology Department/Nonproliferation Technologies Section

Cobert Addis

R. P. Addis, Manager, ATG

SRTC/Measurement Technology Department/Nonproliferation Technologies Section

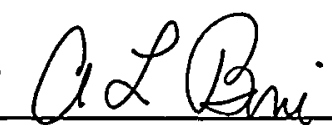

Date: $\quad 12-2-99$

A. L. Boni, Manager, NTS

SRTC/Measurement Technology Department/Nonproliferation Technologies Section 
WSRC-TR-99-00409

November 1999

$\because$

(Blank Page)

• 


\section{ABSTRACT}

An advanced stochastic transport model has been modified to include the removal mechanisms of dry and wet deposition. Time-dependent wind and turbulence fields are generated with a prognostic mesoscale numerical model and are used to advect and disperse individually released particles that are each assigned a mass. These particles are subjected to mass reduction in two ways depending on their physical location. Particles near the surface experience a decrease in mass using the concept of a dry deposition velocity, while the mass of particles located within areas of precipitation are depleted using a scavenging coefficient. Two levels of complexity are incorporated into the particle model. The simple case assumes constant values of dry deposition velocity and scavenging coefficient, while the more complex case varies the values according to meteorology, surface conditions, release material, and precipitation intensity. Instantaneous and cumulative dry and wet deposition are determined from the mass loss due to these physical mechanisms. A useful means of validating the model results is with data available from a recent accidental release of Cesium-137 from a steel-processing furnace in Algeciras, Spain in May, 1998. This paper describes the deposition modeling technique, as well as a comparison of simulated concentration and deposition with measurements taken for the Algeciras release. 


\section{TABLE OF CONTENTS}

1. INTRODUCTION

2. DEPOSITION

2.1 Dry Deposition 2

2.2 Wet Deposition 4

3. ATMOSPHERIC MODELS 4

3.1 Prognostic Mesoscale Model 4

3.2 Transport Model 5

4. SIMULATION OF DEPOSITION IN LPDM

5. APPLICATION 11

6. CONCLUSIONS 14

$\begin{array}{ll}\text { REFERENCES } & 15\end{array}$

$\begin{array}{ll}\text { APPENDICES } & 27\end{array}$

A. Resistance Calculations in Variable Dry Deposition 27

A.1 Aerodynamic Resistance $\left(r_{A}\right) \quad 27$

A.2 Sublayer Resistance $\left(r_{B}\right) \quad 28$

A.3 Surface Resistance $\left(r_{C}\right) \quad 29$

B. Revision to the Input File for LPDM 31 


\section{LIST OF TABLES}

Table 1: RAMS Inpü Characteristics. 18

$\begin{array}{lc}\text { Table 2: LPDM Input Characteristics. } & 18\end{array}$

Table A.1: Canopy Resistance Values $\left(\mathrm{s} \mathrm{m}^{-1}\right)$ as a Function of Vegetation Type.

\section{LIST OF FIGURES}

Figure 1: Schematic representation of different grids used in RAMS and LPDM. A two-grid RAMS simulation domain is depicted, with an LPDM concentration grid located within the finer RAMS grid. A generic plume as released from a source within the LPDM concentration grid is shown to impact all of the grids.

Figure 2: Grid domain utilized in the Algeciras, Spain release simulation. Locations of some of the measurement sites are denoted with ' + ', along with several city names. Dotted lines and numbers indicate latitude ( $2^{\circ}$ increments) and longitude ( $4^{\circ}$ increments).

Figure 3: Synoptic surface conditions using MRF (Aviation) analyses at $1000 \mathrm{mbar}$ at (a) 00 GMT, 30 May 1998, (b) 00 GMT, 31 May, (c) 12 GMT, 01 June, (d) 12 GMT, 03 June. Contours of sea-level pressure (mbar) are shown as solid lines, while arrows represent wind speed and direction. The maximum wind speed indicates the length of the longest arrows. The source location is given by ' $*$ '.

Figure 4: Integrated airborne concentration near the surface after 6 days. Contour values decrease in orders of magnitude from $10^{6} \mu \mathrm{Bq} \mathrm{m}^{-3}$ (darkest shading) to $10^{2} \mu \mathrm{Bq} \mathrm{m} \mathrm{m}^{-3}$ (lightest shading). (a) No deposition, (b) constant deposition, (c) variable deposition.

Figure 5: (a) Total mass (Ci) as a function of time since the start of the LPDM simulation at 6-hr intervals for constant deposition (dotted line, asterisks), variable deposition (dashed line, diamonds), and no deposition (solid line). The total mass released is $80 \mathrm{Ci}(0.8 \mathrm{~g})$. (b) Percentage of mass by height (at $250-\mathrm{m}$ intervals) at three different times for each simulation. Simulation case denoted by markers as in part (a). Linestyle differs for differing times.

Figure 6: Plan view of all LPDM particles and simulated rain-mixing ratio contours in the lowest $150 \mathrm{~m}$ from RAMS. The smallest contour interval is $10^{-6}\left[\mathrm{gm}_{\mathrm{H} 2 \mathrm{O}} \mathrm{gm}_{\text {, } \mathrm{Air}}{ }^{-1}\right]$, with individual RAMS grid locations indicated by a ' $t$ '. The inner contour intervals $10^{-3}$

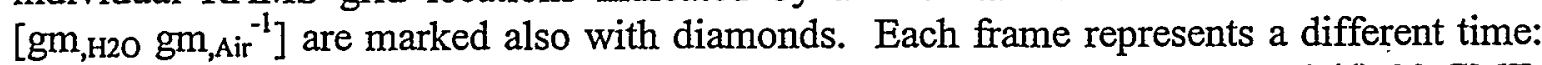
(a) 06 GMT, 30 May 1998, (b) 12 GMT, 30 May, (c) 18 GMT, 30 May, and (d) $00 \mathrm{GMT}$, 31 May. 
Figure 7: Comparison of cumulative dry and wet deposition $\left(\mu \mathrm{Bq} \mathrm{m}^{-2}\right)$ as simulated for the variable deposition case (VAR) and the constant deposition case (CON). Dry deposition values are given with bold solid lines, while the wet deposition values are given with dashed lines. Markers denote the use of variable deposition. Results are shown for six different cities in which measurements were recorded (see Fig. 2 for relative locations). Note the different vertical scales for different locations.

Figure 8: Comparison of measured averaged airborne surface concentration $\left(\mu \mathrm{Bq} \mathrm{m} \mathrm{m}^{-3}\right)$ and simulated averaged surface concentrations over the same time period and for the same locations as in Fig. 7. The solid line indicates no deposition in the LPDM simulation, while the dotted line shows constant deposition calculations. The dashed line indicates variable deposition, while the diamonds represent measured quantities. Simulated averages are for a 12-hr period, while measured values are for 1 to 5-day periods. Note the different vertical scales for different locations. 


\section{INTRODUCTION}

Prognostic atmospheric modeling at the Savannah River Site (SRS) is performed using the Regional Atmospheric Modeling System (RAMS, Pielke et al. 1992). The Lagrangian Particle Dispersion Model (LPDM, Uliasz 1993) is an advanced stochastic atmospheric transport model used to advect and disperse passive tracers subject to the meteorological fields generated in RAMS from sources of varying number and shape. Applications using these models include non-proliferation and emergency response consequence assessments.

The removal of gases and particulate suspensions from the atmosphere by surface transfer mechanisms (dry and wet deposition) is important for assessing contaminant doses. Mesoscale and long-range transport problems are also strongly affected by the resulting plume depletion that occurs when deposition is considered. For instance, Garland et al. (1974) estimate 20 to $30 \%$ of $\mathrm{SO}_{2}$ emissions are removed by dry deposition from the atmosphere. Wet deposition involves absorption of airborne pollutants onto precipitable elements (water droplets, ice particles, graupel, etc.) and is another means by which pollutants reach the earth's surface. Although deposition is very difficult to parameterize due to its dependence on so many quantities (background meteorology, source type, land coverage), it is important to include these physical removal mechanisms into atmospheric transport codes.

This paper discusses the incorporation of dry and wet deposition into a stochastic particle transport model (LPDM). First, background and a general mathematical description of deposition is discussed. Details regarding the transport model are then given, followed by a discussion of the implementation of deposition into the model. The deposition is parameterized in two ways. The first method assumes constant properties in time and space in calculating deposition, while the more complex method determines the deposition as a function of meteorology, land-cover, and precipitation. Finally, an application using the LPDM is discussed using a mesoscale simulation of weather conditions for a release of Cesium-137 from Algeciras, Spain.

\section{DEPOSITION}

A majority of the pollution in the atmosphere is removed by chemical transformations to other compounds, or by transport into the soil, vegetation or water. The concern in this study is with the latter mechanism. Deposition is the transfer of airborne material (gaseous and particulate) to the earth's surface, and may be classified as 'dry' or 'wet', depending on whether or not precipitation is involved. For gases and smaller particulate substances (particle diameters, $d_{p} \leq 10 \mu \mathrm{m}$ ), deposition to surfaces occurs through turbulent diffusion and Brownian motion (Hinds 1982). For larger particulate matter, gravitational settling dominates.

In modeling applications of turbulent diffusion, the surface boundary condition is often described as perfectly reflecting, implying that no physical or chemical interaction of the pollutant with the ground occurs. This is expressed mathematically 


$$
K_{z} \frac{\partial \bar{C}}{\partial \dot{z}}=0 . \text { at } z=0
$$

where $K_{z}$ is the vertical turbulent diffusivity, and $\frac{\partial \bar{C}}{\partial z}$ is the vertical gradient of average concentration, $\bar{C}$. When deposition is introduced into the problem, this surface boundary condition changes such that the surface is partly reflecting/absorbing:

$$
K_{z} \frac{\partial \bar{C}}{\partial z}=v_{D} \bar{C}_{0} \text { at } z=0
$$

In other words, the surface deposition is expressed as a downward mass flux, which is often parameterized as the product of a deposition velocity, $v_{D}$, and the average surface concentration. The stochastic transport model used at SRS already utilizes Eqn. (1) as a surface boundary condition. The interest in this paper is introducing Eqn. (2) into the model as another option.

\subsection{Dry Deposition}

Dry deposition is often calculated using the deposition velocity, $v_{D}$. In general form, this is expressed as the ratio of a dry deposition flux, $F_{D}$, to the earth's surface and the surface concentration, $C$,

$$
v_{D}=\frac{F_{D}}{C}
$$

where the surface concentration is measured at heights on the order of $1 \mathrm{~m}$. If the deposition velocity is known, or can be calculated, then Eqn. (3) may be used to find deposition (mass per area) as the product of the deposition flux and the time interval over which the calculation is made.

Measurements of deposition velocity are discussed in detail in the literature. Overviews may be found in McMahon and Denison (1979), Sehmel (1980), and Businger (1986). In practice, a constant deposition velocity in both time and space is often used. This represents the simple way in which deposition calculations are incorporated into the transport model. The more complex calculation treats the deposition velocity as variable.

This velocity depends on many factors, including boundary layer meteorology, surface characteristics, and the material being deposited. An analogy to electrical current flow across resistances is used to obtain $v_{D}$ (e.g. Hicks et al. 1987, Wesely 1989). Typically, three resistances are determined. The aerodynamic resistance, $r_{A}$, depends on atmospheric (turbulent) 
properties near the earth's surface, while the quasi-laminar resistance, $r_{B}$, represents resistance to transport across the surface boundary layer. Finally, the surface resistance, $r_{C}$, specifies the resistance to transfer into the surface (or canopy resistance).

The quantification is generally separated into gaseous and particulate releases. Gaseous deposition is typically a function of chemical-activity, solubility, and diffusion characteristics, while particulate deposition depends on particulate shape, size distribution, density, impaction, solubility, gravitational settling, and diffusion (Sehmel 1980). For gaseous releases, the formulation is:

$$
v_{D, g}=\left(r_{A, g}+r_{B, g}+r_{C, g}\right)^{-1} \text {. }
$$

With particulate releases, the particles are assumed to stick directly to the surface after penetrating the surface layer. Thus, the resistance into the surface $\left(r_{C}\right)$ is not calculated. The form of deposition velocity used for particulate releases in this study is (Seinfeld 1986):

$$
v_{D, p}=\left(r_{A, p}+r_{B, p}+r_{A, p} r_{B, p} v_{g}\right)^{-1}+v_{g}
$$

where the gravitational settling velocity $\left(\nu_{g}\right)$ of the individual particulate substance is used. This quantity is a function of particulate density, $\rho$, and diameter. It is assumed the air properties (density, $\rho_{\text {air }} \approx 1.0\left[\mathrm{~kg} \mathrm{~m}^{-3}\right]$ and dynamic viscosity, $\mu_{\text {air }} \approx 1.8 \times 10^{-5}\left[\mathrm{~kg} \mathrm{~m}^{-1} \mathrm{~s}^{-1}\right]$ ) are roughly constant, and that the particulate matter are spherical in shape. Accounting for slip for very small particles $\left(d_{p}<0.1 \mu \mathrm{m}\right)$ using the Cunningham correction factor, $\mathrm{Cu}$, the gravitational settling velocity may be expressed (Hinds 1982):

$$
v_{g}=\frac{d_{p}^{2} g\left(\rho_{p}-\rho_{\text {air }}\right) C u}{18 \mu_{\text {air }}} .
$$

The correction factor is a function also of the mean free path of air $\left(\lambda \approx 6.6 \times 10^{-8} \mu \mathrm{m}\right)$ (Hinds 1982):

$$
C u=\left\{\begin{array}{cc}
1+\lambda / d_{p}\left[2.514+0.800 \exp \left(-0.55 \lambda / d_{p}\right)\right] & , d_{p} \leq 1.0 \mu \mathrm{m} \\
1 & , d_{p}>1.0 \mu \mathrm{m}
\end{array} .\right.
$$

Note that in all of these applications, it is assumed that particle motion is within the Stokes regime $\left(d_{p} \leq 20 \mu \mathrm{m}\right)$. Details regarding the calculations of the individual resistances may be found in Appendix A. 


\subsection{Wet Deposition}

Wet deposition occurs through rainout (within cloud scavenging) and washout (below cloud scavenging). Detailed theoretical analysis may be found in Slinn (1984). Due to the great uncertainty in precipitation scavenging measurements, and in generating precipitation within the mesoscale model, a simplified approach is taken in this study. The removal process is parameterized as a first-order decay process. A standard first-order differential equation

$$
\frac{d C}{d t}=-\Lambda C
$$

is used to relate this reduction mechanism to concentration (or mass). The washout (or scavenging) coefficient, $\Lambda$, (units of inverse time) is commonly related to rainfall rates. In the simplified deposition calculations, the washout coefficient is a user-defined constant value in those areas in which rainfall $(R)$ exists:

$$
\Lambda= \begin{cases}\Lambda_{0}, & R>0 \\ 0, & R=0\end{cases}
$$

For the more complex treatment, the washout coefficient is a function of the rate at which precipitation is falling:

$$
\Lambda=\left\{\begin{array}{c}
A\left(P_{R}\right)^{B}, R>0 \\
0, \quad R=0
\end{array}\right.
$$

where the constants are $A=10^{-4}$ and $B=0.8$ (ApSimon et al. 1988), and the precipitation rate, $P_{R}$, is expressed in $\left[\mathrm{mm} \mathrm{hr}^{-1}\right]$.

\section{ATMOSPHERIC MODELS}

\subsection{Prognostic Model}

The atmospheric mesoscale model used in this study is the Regional Atmospheric Modeling System (RAMS), as described in Tripoli and Cotton (1982) and Pielke et al. (1992). A wide range of atmospheric motions may be studied with this three-dimensional primitive-equation, finite-difference model due to the use of a two-way nested grid system. Incorporation of topographic features occurs through the use of a terrain-following vertical coordinate system, while turbulence is parameterized using Mellor and Yamada's level 2.5 scheme (Mellor and Yamada 1982), as modified by Helfand and Labraga (1988) for growing turbulence. 
Initial and lateral boundary conditions for the model are driven by National Oceanic and Atmospheric Administration (NOAA) National Centers for Environmental Prediction (NCEP) large-scale analyses and forecasts, which contain three-dimensional meteorological fields of winds, temperature, moisture, and more at varying time-intervals (typically 3,6 or 12 hours): The forecast information is used for lateral boundary conditions using linear time interpolation, based on the Davies relaxation assumption (Davies 1976). Large-scale data are obtained from both the Air Resources Laboratory and Weather Services International. (WSI 1997).

Surface characteristics are incorporated with a soil model (McCumber and Pielke 1981, Tremback and Kessler 1985) and vegetation parameterization (the Biosphere Atmosphere Transfer Scheme, BATS, Dickinson et al. 1986). Variable fractional land coverage and seasurface temperatures are also used for input to the model.

The microphysical parameterization available within RAMS (Cotton et al. 1982, 1986) was utilized to generate precipitation for use in estimating wet deposition. Although interactions of rain water droplets with graupel, hail, snow, pristine ice, or aggregates are modeled in the parameterization, the generation of rain water is the only item considered here. A mean droplet diameter is specified, from which rain mixing ratio is prognosed. This value is passed on to the transport model for use in wet deposition calculations.

\subsection{Transport Model}

The stochastic transport model used in this study is the Lagrangian particle dispersion model (LPDM, McNider and Pielke 1988, Uliasz 1993). Input for LPDM comes in the form of threedimensional wind and turbulence (Gaussian) fields generated by an atmospheric model. A large number of particles may be released and their positions tracked by numerically solving the Langevin stochastic differential equation for subgrid-scale turbulent velocites, $u_{i}^{\prime \prime}$ (Gifford 1982)

$$
\frac{\mathrm{d} u_{i}^{\prime \prime}}{\mathrm{d} t}=-\frac{u_{i}^{\prime \prime}}{T_{L_{i}}}+\frac{d u_{i}^{\prime \prime \prime}}{d t}(i=1,2,3)
$$

where $T_{L}$ are Lagrangian time scales and $\mathrm{d} u_{i}^{\prime \prime \prime}$ are random velocity increments.

Lagrangian autocorrelations, $R_{L, i}$, arise by modeling the atmospheric diffusion as a Markov chain process. These functions are expressed in exponential form as the ratio of the model timestep, $\Delta t$, and the Lagrangian timescale for each direction

$$
R_{L, i}(\Delta t)=\exp \left(\frac{-\Delta t}{T_{L_{i}}}\right)(i=1,2,3) .
$$

Particle positions are then determined from 


$$
x_{i}(t+\Delta t)=x_{i}(t)+\left(u_{i}+u_{i}^{\prime \prime}\right) \Delta t(i=1,2,3)
$$

where $x_{i}$ is the spatial direction, $t$ is the dispersion model time, and $u_{i}$ is the mean velocity component obtained from RAMS. It is assumed in the discussions to follow that $(i=1,2,3)$ are denoted $(i=I, J, K)$ and correspond to west-east, south-north, and vertical directions, respectively.

Each particle represents a discrete element of pollutant mass which may be used in the calculation of concentration. Concentrations are estimated using the "cell" method, whereby the mass of individual particles in a physical cell is summed. The initial mass of each particle released into the atmosphere is determined from a user-defined mass release rate. This is a discrete method in which the concentration estimate is assumed to be constant throughout the sampling volume (Moran 1992). A distinction is made between the grid on which RAMS simulations are performed and the LPDM concentration grid, as denoted in Fig. 1. Although the user may configure the transport grid to coincide with one of the RAMS grids, it is more often chosen to be a subset near the release point. This feature is noted because in LPDM, particle locations are denoted with reference to the RAMS coarse grid, whereas concentration and deposition calculations are performed on the LPDM concentration grid.

It is also important to note that in LPDM, a collection of virtual 'particles' makes up the mass of pollutant released into the atmosphere. A particle released in LPDM should not be confused with aerosols (denoted in this paper as particulate suspension, matter, etc.) whose characteristics (i.e. diameter, settling velocity, etc.) may be totally different. Each particle released in LPDM is identified by its 'attributes', including location, turbulent velocity fluctuations, and age, as well as source location, particle species, and RAMS grid number on which the particle exists. The deposition is assumed to be dependent on the particle species, and multiple species may be released for a given source location. Output consists of instantaneous and cumulative deposition at the same time intervals as concentration output, although deposition calculations are performed at every. timestep.

Previously, mass concentration was determined by counting the number of particles within a cell, dividing by the volume of the cell, and multiplying by a mass release rate. In other words, each released particle represented an equal mass. Note that radioactive decay was also included in this calculation. The major change to LPDM with the inclusion of deposition is the addition of a mass attribute for each particle. The initial mass of each released particle is assumed to be the same for a given source location and species, as determined by the release rate, $\dot{m}$, the number of particles released per timestep, $N$, and the timestep:

$$
m_{n}=\frac{\dot{m} \Delta t}{N}
$$


In addition, a particle diameter attribute is assigned. The user specifies a diameter size distribution along with a particle density. Both values are used to define the gravitational settling velocity (Eqn. (6)) for each particle. This is important for the particulate deposition calculations, although the user may specify a gaseous release with gravitational settling. However, the density ${ }^{\circ}$ of particulate matter is typically 1000 to $3000 \mathrm{~kg} \mathrm{~m}^{-3}$, (Hinds 1982), whereas gaseous density is generally 2 to 3 orders of magnitude smaller, leading to much lower settling velocities. Therefore, gravitational settling is often ignored for gaseous releases. It is important to realize that the diameter attribute is not a function of LPDM particle mass, but rather a constant whose value is set as individual particles are released in LPDM. The size distribution is used to simulate typical particulate (aerosol) suspensions within the atmosphere. If each LPDM particle represented an individual aerosol, then releases of $10^{10}$ to $10^{12}$ particles or more would be needed for a simulation, which is computationally impossible with current computing capabilities.

\section{SIMULATION OF DEPOSITION IN LPDM}

The introduction of the partly reflecting/absorbing boundary condition (Eqn. (2)) through use of the deposition velocity (Eqn. (3)) is now discussed. The idea is to reduce the mass of each LPDM particle if it is subjected to a depositing mechanism (i.e. near the surface or within precipitation). It is assumed that the surface concentration in Eqn. (3) is calculated within the lowest model layer within LPDM $(\sim 10$ to $25 \mathrm{~m})$. Equal depletion of all particles within a grid cell at a given time is also assumed.

Consider the following variable definitions:

$$
\begin{aligned}
& m_{n} \quad \equiv \text { mass of particle } n \text { [gm, (or Ci)] } \\
& M \quad \equiv \text { Total mass of all particles, of which there are } N \text { [gm] } \\
& C \quad \equiv \text { concentration }\left[\mathrm{gm} \mathrm{m}^{-3}\right] \\
& F \quad \equiv \text { dry deposition flux }\left[\mathrm{gm} \mathrm{m}^{-2} \mathrm{~s}^{-1}\right] \\
& \Delta t \quad \equiv \text { timestep [s] } \\
& \Delta x_{C}, \Delta y_{C}, \Delta z_{C} \quad \text {. } \equiv \text { grid spacing in horizontal and vertical concentration grid [m] } \\
& \left.V_{C}=\Delta x_{C} \Delta y_{C} \Delta z_{C} \equiv \text { volume of concentration grid cell [ } \mathrm{m}^{3}\right] \\
& A_{C}=\Delta x_{C} \Delta y_{C} \quad \equiv \text { horizontal area occupied by a concentration grid cell }\left[\mathrm{m}^{2}\right] \\
& N_{C} \quad \equiv \text { number of particles within a concentration grid cell } \\
& \Delta x_{R}, \Delta y_{R}, \Delta z_{R} \quad \equiv \text { grid spacing in horizontal and vertical for RAMS coarse grid[m] } \\
& \left.V_{R}=\Delta x_{R} \Delta y_{R} \Delta z_{R} \equiv \text { volume of RAMS coarse grid cell [ } \mathrm{m}^{3}\right] \\
& A_{R} \quad \equiv \text { horizontal area occupied by the RAMS coarse grid cell }\left[\mathrm{m}^{2}\right] \\
& N_{R} \quad \equiv \text { number of particles within the RAMS coarse grid cell }
\end{aligned}
$$

The dimensions of the RAMS coarse grid [m] and the concentration grid [m] are initially determined in an effort to determine the cell volumes in which summation of mass or deposition occurs. 
After particles are emitted into the simulation domain and assigned individual masses, the mass loss of these particles due to wet and dry deposition, as well as radioactive decay is calculated. Before advecting and dispersing particles according to RAMS-generated winds and turbulence fields, each particle is checked to see if its mass requires reduction.

A subroutine has been added which finds the mass lost due to radioactive decay and wet deposition within a computational loop which concurrently determines the Cartesian $(I, J, K)$ locations of each particle on the coarse RAMS grid. Radioactive decay depends only on the timestep, mass of the particle, and the half-life $(\Gamma,[s])$ of the source material. Thus, for radioactive decay, the mass depletion fraction may be written

$$
r_{R A D, n}=\left(1-\exp \left[\frac{-\ln (2) \cdot \Delta t}{\Gamma}\right]\right)
$$

For wet deposition, mass is depleted according to the washout coefficient only in those coarse RAMS grid cells where rain mixing-ratio has been generated in RAMS. The fractional mass loss may be expressed as

$$
r_{W, n}=1-\exp \left(-\Lambda_{i, j, k} \cdot \Delta t\right)
$$

where the washout coefficient $\left[\mathrm{s}^{-1}\right]$ for the simple and complex cases are given by Eqns. (9) and (10), respectively.

Note that RAMS reports the rain mixing-ratio, $R_{R}$, $\left[\mathrm{kg}_{\mathrm{H}_{2} 0 \mathrm{~kg}_{\mathrm{Air}}}{ }^{-1}\right]$ as a three-dimensional variable in time. This value is first linearly interpolated in time to a value representative of the current timestep in LPDM. The precipitation rate is then determined using (Tripoli and Cotton 1982)

$$
P_{R, i, j, k}=V_{T, R} R_{R, i, j, k}\left(\frac{\rho_{A i r, i, j, k}}{\rho_{H_{2} O}}\right)
$$

in which the terminal settling velocity of raindrops, $V_{T, R}$, is assigned according to Tripoli and Cotton (1980). Assuming a constant air density $\left(1.28\left[\mathrm{~kg} \mathrm{~m}^{-3}\right]\right)$, and a characteristic rain droplet diameter of $540 \mu \mathrm{m}, V_{T, R}=5.93\left[\mathrm{~m} \mathrm{~s}^{-1}\right]$, which is used in the conversions here. The resulting precipitation rate in then converted to [mm hr-1] and Eqn. (10) is used to find the scavenging coefficient. Note that the characteristic droplet diameter used in the calculation of terminal settling velocity is the default setting in the RAMS microphysics parameterization for constant droplet diameter calculations.

A series of "counting" routines have been created to determine mass-related items in a given cell, either on the RAMS coarse grid, or within the finer concentration grid (see Fig. 1). Looping over the total number of particles, sums over each cell are made depending on the Cartesian location 
of the particles. The first routine determines the total mass of particles within the coarse RAMS grid cells at the surface (denoted as $k=0$ in the equations), which are subject to dry deposition

$$
M_{R, i, j, 0}=\sum_{n=1}^{N_{R, L, j, 0}} m_{n}
$$

A dry deposition flux [ $\mathrm{gm} \mathrm{m}^{-2} \mathrm{~s}^{-1}$ ] is determined by taking the mass within in each surface cell and dividing by the volume, then multiplying by the deposition velocity,

$$
F_{i, j}=\frac{M_{R, i, j, 0}}{V_{R, i, j, 0}} v_{d}
$$

This flux can then be multiplied by the timestep to give a deposited mass $\left[\mathrm{gm} \mathrm{m} \mathrm{m}^{-2}\right]$ to the surface within a cell,

$$
D_{R, D R Y_{i, j}}=F_{i, j} \Delta t
$$

The fraction of mass (unitless) retained within each cell due to dry deposition is determined from knowledge of the original total particle mass within the cell, and the total amount that is depleted using

$$
r_{D, i, j}=\frac{M_{R, i, j, 0}-D_{R, D R Y} A_{R, j}}{M_{R, i, j, j}}
$$

At this point, equal depletion by mass of each particle within the RAMS coarse grid cell is assumed. Another counting routine depletes the mass of each particle in the cell based on this fractional depletion,

$$
m_{R E T, D R Y_{n}}=r_{D, i, j} m_{n},
$$

which yields an updated mass. The final step is to find the mass depleted within each concentration grid cell by subtracting the mass retained due to dry deposition for each particle from the original particle mass,

$$
M_{C, i, j, 0}=\sum_{n=1}^{N_{C, S, j, 0}}\left(m_{n}-m_{R E T, D R Y, n}\right) \text {. }
$$

Note that this formulation implies that all concentration grid cells within a RAMS coarse grid cell have the same mass reduction factor, $r_{D, i, j}$. Instantaneous dry deposition [gm $\mathrm{m}^{-2}$ ] to the surface for each concentration grid cell is then found by dividing by surface grid cell area 


$$
D_{C, D R Y_{i, j}}=\frac{M_{C, i, j, 0}}{A_{C}} .
$$

Wet deposition is determined in a similar manner using the previously determined mass, and counting within the various concentration grid cells. The total mass accumulated at the surface due to wet deposition may be expressed

$$
M_{W, i, j}=\sum_{k=1}^{K} \sum_{n=1}^{N_{C, l, j, k}} r_{W, n} m_{n}
$$

where a summation over all vertical grid cells in a column has been performed. Thus, the instantaneous wet deposition to the surface $\left[\right.$ gm $\mathrm{m}^{-2}$ ] due to the existence of rainfall is written

$$
D_{C, W E T_{i, j}}=\frac{M_{W, i, j}}{A_{C}}
$$

where the mass loss has been divided by the surface cell area.

Cumulative deposition values are continuously summed after each timestep (a total of $T$ ) using

$$
D_{C, D R Y_{-} S_{U} M_{i, j}}=\sum_{l=1}^{T} D_{C, D R Y_{i, j}}
$$

and

$$
D_{C, W E T_{-} S_{U} M_{i, j}}=\sum_{l=1}^{T} D_{C, W E T_{i, j}} .
$$

In addition, the mass of each LPDM particle is then updated after this entire process by subtracting out the loss due to radioactive decay, dry, and wet deposition:

$$
m_{N E W}=m_{R E T, D R Y, n}-\left(r_{W, n}+r_{R A D, n}\right) m_{n}
$$

In this manner, the mass of each particle is depleted according to various physical mechanisms, and deposition values are formulated according to this change in particle mass. Logic within the code is used to account for the complexity of the deposition calculation (see Appendix B for further details). 
The counting routine for concentration has been altered to sum the particle mass within a given concentration grid cell volume. Mass concentrations are then determined by simply dividing by the volume of the cell

$$
C_{C, i, j, k}=\frac{M_{C, i, j, k}}{V_{C}}
$$

Finally, plots of instantaneous and cumulative dry and wet deposition are generated for each source location and included in the National Center for Atmospheric Research (NCAR) graphical output (Clare and Kennison 1989). Plots of deposition for individual species are not generated; the deposition for a given source location is summed over all species.

\section{APPLICATION}

As a result of melting a medical radiotherapy source, a steel-processing furnace in Algeciras, Spain released Cesium-137 leading to radioactive contamination covering much of southern Europe during late May and early June 1998. Since integrated and averaged air concentration measurements exist during this time, this event has been chosen for simulation as a means of evaluating the deposition modeling effort.

The mesoscale model (RAMS) was used to simulate meteorological conditions in Europe for the period covering 12 GMT, 29 May 1998 to 00 GMT, 05 June 1998. The RAMS characteristics are summarized in Table 1 . The single grid simulation was initialized using large-scale dynamical conditions obtained from the NCEP Medium Range Forecast (MRF) Aviation model. This model also provided lateral boundary conditions at 6-hr intervals. Aviation analyses were used at 00 and $12 \mathrm{GMT}$, while forecasts were utilized at 06 and $18 \mathrm{GMT}$. In addition, surface and upper-air (00 and $12 \mathrm{GMT}$ only) meteorological reports for fixed land stations were blended with the large-scale gridded information. Meteorological conditions used as input for LPDM were generated on an hourly basis. The geographic domain coverage for the transport model is illustrated in Fig. 2, along with many of the measurement sites.

A series of maps (Fig. 3) indicating large-scale surface winds and pressure (taken from $1000 \mathrm{mb}$ Aviation analyses) depict the general synoptic patterns through the period. The emphasis here is on describing pertinent conditions to the source release, which occurred around 01:30 GMT, 30 May 1998. Southwesterly winds existed near Algeciras during the release due to low pressure centered off the western coast of France (00 GMT, 30 May, Fig. 3a). This acted to drive pollutants along the southeastern Spanish border before backing to the north from a ridge of high pressure located through central Europe. Over the next 24 hours, the low-pressure system intensified while moving to the western coast of England (Fig. 3b). Winds near the source shifted to westerly with strong southerly flow through the Mediterranean Sea and into eastern France. 
The low pressure remained off the western coast of England while high pressure moved into the Mediterranean Sea south of Italy by 12 GMT, 01 June (Fig. 3c). This resulted in southwest to west winds through northern Italy, Switzerland, and Austria. Following this, the majority of the pollutant near the surface was caught up in the clockwise flow about the high pressure near southern Italy. This high pressure weakened, leading to strong southerly flow through Sardinia and Corsica, and strong northerly flow through the Adriatic Sea and the Balkan States by 12 GMT, 03 June (Fig. 3d). Wind in central Europe became lighter and varied from southerly to westerly in direction, which resulted in pollutant traversing northern Italy and Austria before traveling south through the Balkan States. By the end of the period (00 GMT, 05 June), winds became light and variable in the northern Balkans, while stronger northerly winds remained through Greece.

Three separate transport simulations were conducted. The first simulation assumes no deposition occurs (Eqn. (1)). Constant deposition parameters which are typically used in deposition modeling applications $\left(v_{D}=0.1 \mathrm{~cm} \mathrm{~s}^{-1}, \Lambda=0.0001 \mathrm{~s}^{-1}\right)$ are used in the second simulation (i.e. the 'simple' case of deposition), while variable deposition (Eqns. (5) and (8), 'complex' deposition) is assumed to occur in the third model run. Input conditions for LPDM are summarized in Table 2. Note that the release is assumed to be in particulate form. Using estimates of the source release (Vogt et al. 1999), each simulation assumed $80 \mathrm{Ci}$ (equivalent to $0.8 \mathrm{~g}$ for this species) was released over a 30 minute period at $50 \mathrm{~m}$ AGL beginning at 01:30.GMT, $30 \mathrm{May}, 1998$.

Integrated surface concentration is shown after the 6-day period in Fig. 4 for the three simulations. The darker shading indicates higher concentration in orders of magnitude. Contaminant is seen to spread northeasterly from the release out over the Mediterranean Sea, southern France, Italy, and into Eastern Europe. In all cases, the most intense surface concentration is near the source, and on a line east-northeast through the island of Corsica and into central Italy, a result of the low pressure system near France and England (Fig. 3a).

As seen in Fig. 4a, plume migration assuming no deposition is more widespread than for either of the other cases. Concentrations of greater than $100 \mu \mathrm{Bq} \mathrm{m} \mathrm{m}^{-3}$ are simulated as far north as northern Germany. Assumption of constant deposition (Fig. 4b) in this case yields smaller airborne (surface) concentrations than when it is allowed to vary as a function of meteorology, surface characteristics, and rainfall intensity (Fig. 4c). This implies larger total mass loss, leading to greater deposition.

Figure 5a illustrates the difference in total mass lost as a function of time for the simulations. A large portion of the overall mass is lost within the first 18 hours of the simulation (more than half for the variable deposition case and more than $80 \%$ assuming constant deposition). This sudden drop is a combination of both depositing mechanisms. Particles are released very near the surface and are being deposited out due to dry deposition mechanisms. However, as indicated in Figs. 6(a-c), rainfall was also simulated near the source during this time period, resulting in a large percentage of mass being quickly deposited out due to scavenging mechanisms. After 24 hours, the majority of the particles had moved east of Spain into the Mediterranean Sea (Fig. 6d) where no rain mixing ratio was simulated, resulting in smaller mass loss rates shown in Fig. 5a. 
After 3 days, particles begin to leave the LPDM grid domain, resulting in mass loss for the case of no deposition. By this time, roughly one-third of the original mass $(80 \mathrm{Ci}$, or $0.8 \mathrm{~g}$ ) remained for the variable deposition simulation. This mass loss may be changed through modification of the deposition velocity and the scavenging coefficient.

Another means of decreasing the mass loss is to raise the source relative to the surface, such that particles are not subject to the surface conditions. The percentage of effluent mass as a function of distance above ground for each of the simulations at three different times (Fig. 5b) reveals a very high percentage near the surface initially, which is not surprising since all particles are released near ground level. After three days (dotted lines), the peak of the mass distribution lifts to $250-\mathrm{m}$ above ground, while a more even vertical distribution to higher levels is evident. This is a result of particles being lifted higher into the atmosphere due to flow through mountainous terrain and/or frontal passage. By the end of the simulation, the largest percentage of mass is again near the ground (dashed lines), as many of the particles have returned to the surface. However, as evidenced by the increased mass percentages above $2000 \mathrm{~m} \mathrm{AGL}$, a non-trivial amount of particles are still being elevated. The simulation with no deposition exhibits higher mass totals aloft compared with the deposition simulations as a result of scavenging for the latter simulations. This reduced mass at higher elevations also accounts for the larger surface mass percentages. In other words, the inclusion of wet deposition has lowered the vertical center of mass over the entire simulation domain.

The comparative effects of wet and dry deposition are illustrated for six different cities in Fig. 7. The cumulative dry and wet deposition for both cases is given as function of time over the 6-day transport simulation. The deposited mass due to dry deposition is generally higher for the case when a constant dry deposition velocity is specified, whereas the wet deposition in the variable case exceeds the constant scavenging coefficient case. This implies the calculated deposition velocity in the variable case was typically lower than the constant $0.1 \mathrm{~cm} \mathrm{~s}^{-1}$, while the scavenging coefficient was higher. The dominance of wet deposition in Figs. 7(a, e, f) using a variable scavenging coefficient is in agreement with the results of Brandt (1998), who modeled dry and wet deposition for the Chernobyl release of 1986. He found that wet deposition was the dominant removal mechanism for Cesium-137, and that his constant value of dry deposition velocity $\left(0.2 \mathrm{~cm} \mathrm{~s}^{-1}\right)$ was too large.

Comparisons of measured airborne concentrations near the surface (Vogt et al. 1999) with the three simulations are depicted in Fig. 8 for the same locations and time period as in Fig. 7. The simulated concentrations are averaged over a 12-hr period, beginning at $00 \mathrm{GMT}, 30 \mathrm{May}$, and continuing until $00 \mathrm{GMT}, 05$ June. The measured values are typically given in 1 to 5-day averages. For the given measurement period, the value is merely shown repeatedly at $12-\mathrm{hr}$ intervals on the graph. It is difficult to make general statements regarding the strength of one simulation over another given the limited data with which to compare results and the uncertainty of the source strength and location (Vogt et al. 1999). In all cases, the variable deposition simulation yields higher concentrations than the constant deposition case, in agreement with Fig. $5 a$. 
Simulated concentrations in Marcoule, France (Fig. 8a) indicate peak values in all cases occurring at roughly the same time as measurements. This is not the case for Ispra, Italy, where the simulated peak airborne concentrations occur 12 hours early. As seen in most locations, theexistence of deposition in the model aids in reducing the airborne surface concentration nearer to measured levels compared to the assumption of no deposition.

In summary, deposition enhanced the simulation predictions, especially further downwind of the release point (eastern Italy to Austria). The constant deposition velocity of $0.1 \mathrm{~cm} \mathrm{~s}^{-1}$ appears to be too high in this instance. Based on measurements, the plume footprint depicted in Fig. 4, which tends to exhibit maximums on an east-northeasterly line through Corsica and central Italy, is slightly south of the actual plume. The highest measured concentrations tended to be in northern Italy (i.e. Milan) and southern France (i.e. Toulon, Nice). Concentrations for all simulations were underestimated in these regions (not shown). Therefore, errors in meteorology play a major role in concentration estimates.

\section{CONCLUSIONS}

A stochastic atmospheric Lagrangian particle transport model has been modified to incorporate both dry and wet deposition. Each particle is initially assigned a mass, which is depleted according to the various mechanisms discussed in the paper. A set of simulations has been performed and compared with measured data obtained during an accidental release of Cesium137 in Algeciras, Spain. No removal mechanism is employed in the first case, while constant wet and dry deposition rates are assumed in the second case, and variations in deposition according to surface conditions, meteorology, and rainfall intensity are used in the third case.

While definitive conclusions regarding the 'best' simulation are difficult to make, due to potential error from sources other than the deposition models themselves, it is seen that reductions in airborne surface concentration due to inclusion of the mass removal mechanisms can result in improvements in the transport calculations. Underestimates in concentration using constant deposition velocities and scavenging coefficients can be corrected by modifying their values. However, as shown in much of the literature, these values are not constant in nature, and the added physical mechanisms involving aerodynamic, sublayer, and surface resistance, as well as variations in wet deposition due to rainfall intensity, improve the basic premise behind the modeling effort. 


\section{REFERENCES}

ApSimon (1988): The use of weather radar in assessing deposition of radioactivity from Chernobyl across England and Wales. Atmos Environ., 22 (9), 1895-1900.

Arritt, R. W., R. A. Pielke, and M. Segal (1988): Variations of sulfur dioxide deposition velocity resulting from terrain-forced mesoscale circulations. Atmos. Environ., 22 (4), 715-723.

Arritt, R. W. (1991): A numerical modeling technique for estimating sulfur dioxide dry deposition due to local source emissions. J. Air Waste Manage. Assoc., 41, 1341-1347.

Brandt, J. (1998): Modelling Transport, Dispersion and Deposition of Passive Tracers from Accidental Releases. Ph. D. Thesis, Ministry of Environment and Energy, National Environmental Research Institute and Ministry Research and Information Technology, Risø National Laboratory, 307 pages.

Businger, J. A. (1986): Evaluation of the accuracy with which dry deposition can be measured with current micrometeorological techniques. J. Climate Appl. Meteorol., 25, 1100-1124.

Businger, J. A., J. C. Wyngaard, Y. Izumi, and E. F. Bradley (1971): Flux-profile relationships in the atmospheric surface layer. J. Atmos. Sci., 28, 181-189.

Clare F. and D.' Kennison (1989): NCAR Graphics Guide to New Utilities, Version 3.00. NCAR/TN-341+STR, University Corporation for Atmospheric Research, Boulder, Colorado.

Clarke, R. H. (1970): Recommended methods for the treatment of the boundary layer in numerical models. Aust. Meteor. Mag., 18, 51-73.

Cotton, W. R., M. A. Stephens, T. Nehrkorn, and G. J. Tripoli (1982): The Colorado State University three-dimensional cloud model--1982. Part II: An ice phase parameterization. $J$. Rech. Atmos., 16, 295-320.

Cotton, W. R., G. J. Tripoli, R. M. Rauber, and E. A. Mulvihill (1986): Numerical simulation of the effects of varying ice crystal nucleation rates and aggregation processes on orographic snowfall. J. Clim. Appl. Meteor., 25, 1658-1680.

Davies, H. C. (1976): A lateral boundary formulation for multi-level prediction models. Quart. J. Roy. Met. Soc., 102, 405-418.

Dicksinson, R. E., A. Henderson-Sellers, P. J. Kennedy, and M. F. Wilson (1986): BiosphereAtmosphere Transfer Scheme (BATS) for the NCAR Community Climate Model. National Center for Atmospheric Research Tech. Note NCAR/TN-275+ST, 69 pp. 
Garland, J. A., D. H. Atkins, C. J. Readings, and S. J. Caughey (1974): Deposition of gaseous sulphur dioxide to the ground. Atmos. Environ., 8, 74-79.

Gifford, F. A. (1982): Horizontal diffusion in the atmosphere: a Lagrangian-dynamical theory: Atmos. Environ., 16, 505-512.

Helfand H. M., and J. C. Labraga (1988): Design of a nonsingular level 2.5 second-order closure model for the prediction of atmospheric turbulence. J. Atmos. Sci., 45, 113-132.

Hicks, B. B., D. D. Baldocchi, T. P. Meyers, R. P. Hosker Jr., and D. R. Matt (1987): A preliminary multiple resistance routine for deriving dry deposition velocities from measured quantities. Water, Air and Soil Pollut., 36, 311-330.

Hinds, W. C. (1982): Aerosol Technology. Properties, Behavior, and Measurement of Airborne Particles, John Wiley \& Sons, New York, pp. 45, 397-408.

Mahrer, Y. and R. A. Pielke (1977): A numerical study of the airflow over irregular terrain. Contributions to Atmospheric Physics, 50, 98-113.

McCumber M. C., and R. A. Pielke (1981): Simulation of the effects of surface fluxes of heat and moisture in a mesoscale numerical model: I. Soil layer. J. Geophys. Res., 86 (C10), 9929-9938.

McMahon, T. A.: and P. J. Denison (1979): Empirical atmospheric deposition parameters--a survey. Atmos. Environ., 13, 571-585.

Mellor G. L. and T. Yamada (1982): Development of a turbulent closure model for geophysical fluid problems. Rev. Geophys. Space Phys. 20 (10), 851-875.

Moran, M. D. (1992): Numerical Modelling of Mesoscale Atmospheric Dispersion, Ph. D. dissertation, Colorado State University, Department of Atmospheric Science, Paper No. 513.

Pielke, R. A. (1984): Mesoscale Meteorological Modeling, Academic Press, Orlando, Florida, p. 153.

Pielke, R. A., W. R. Cotton, R. L. Walko, C. J. Tremback, W. A. Lyons, L. D. Grasso, M. E. Nicholls, M. D. Moran, D. A. Wesley, T. J. Lee, and J. H. Copeland (1992): A comprehensive meteorological modeling system--RAMS. Meteor. Atmos. Phys., 49, 69-91.

Sehmel, G. A. (1980): Particle and gas dry deposition: a review. Atmos. Environ., 14, 981-1011.

Seinfeld, J. H. (1986): Atmospheric Chemistry and Physics of Air Pollution, John Wiley, New York. 
Slinn, W. G. N. (1984): Precipitation Scavenging. In Atmospheric Science and Power Production (D. Randerson, ed.), pp. 466-532. U. S. Department of Energy, Technical Information Center, Oak Ridge, TN.

Tremback C. J. and R. Kessler (1985): A surface temperature and moisture parameterization for use in mesoscale numerical models. Preprints, Seventh Conf. on Numerical Weather Prediction, Montreal, Quebec, Canada, Amer. Meteor. Soc., 355-358.

Tripoli G. J. and W. R. Cotton (1980): A numerical investigation of several factors contributing to the observed variable intensity of deep convection over South Florida. J. Appl. Meteor., 19, 1037-1063.

Tripoli G. J. and W. R. Cotton (1982): The Colorado State University three-dimensional cloud/mesoscale model--1982, Part I: General theoretical framework and sensitivity experiments. J. Rech. Atmos., 16, 185-219.

Uliasz, M. (1993): The atmospheric mesoscale dispersion modeling system. J. Appl. Meteor., 32, 139-149.

Vogt P. J., B. M. Pobanz, F. J. Aluzzi, R. L. Baskett, and T. J. Sullivan (1999): ARAC simulation of the Algeciras, Spain steel mill CS-137 release. UCRL-JC-131330, Lawrence Livermore National Laboratory, Livermore, California, $51 \mathrm{pp}$.

Walcek, C. J., R: A. Brost, J. S. Chang, and M. L. Wesely (1986). $\mathrm{SO}_{2}$, sulfate, and $\mathrm{HNO}_{3}$ deposition velocities computed using regional landuse and meteorological data. Atmos. Environ., 20 (5), 949-964.

Weather Services International (1997): Weather for Windows, User's Manual. Document 990W4WW-00, WSI Corporation.

Wesely, M. L. (1989): Parameterization of surface resistances to gaseous dry deposition in regional-scale numerical models. Atmos. Environ., 23 (6), 1293-1304.

Wesely, M. L. and B. B. Hicks (1977): Some factors that affect the deposition rates of sulfur dioxide and similar gases on vegetation, J. Air Pollut. Control Ass., 27, 1110-1116. 
Table 1: RAMS Input Characteristics.

\begin{tabular}{|l|c|l|c|}
\hline \multicolumn{4}{|c|}{ Spatial and Temporal Characteristics } \\
\hline Simulation Time & $156 \mathrm{hr}$ & Timestep & $45 \mathrm{~s}$ \\
\hline Horizontal Grid Points $(x, y)$ & $63 \times 58$ & Grid Spacing & $50 \mathrm{~km}$ \\
\hline Vertical Grid Points & 25 & Model Top & $17170 \mathrm{~m}$ \\
\hline Vertical Spacing: Surface & $60 \mathrm{~m}$ & Vertical Spacing: Top & $1250 \mathrm{~m}$ \\
\hline Pole Latitude & $46.0^{\circ} \mathrm{N}$ & Pole Longitude & $6.0^{\circ} \mathrm{E}$ \\
\hline \multicolumn{3}{|c|}{ Surface Input } \\
\hline Topography & $2^{\prime \prime}$ USGS \\
\hline Vegetation & $1^{\prime \prime}$ USGS \\
\hline Sea Surface Temperature & Global 1 ${ }^{\circ}$ horizontal resolution obtained monthly \\
\hline \multicolumn{3}{|c|}{ Other } \\
\hline Lateral Boundary Condition & Davies relaxation (1976) toward large scale; $f=300 \mathrm{~s}$ \\
\hline Radiation (short; long) & Mahrer and Pielke (1977); Chen and Cotton (1983); $f=900 \mathrm{~s}$ \\
\hline Convective Parameterization & Modified Kuo cumulus (Tremback 1990); $f=900 \mathrm{~s}$ \\
\hline Turbulence Parameterization & Modified Mellor-Yamada 2.5 (Helfand and Labraga 1988) \\
\hline
\end{tabular}

Table 2: LPDM Input Characteristics.

\begin{tabular}{|l|l|l|l|}
\hline \multicolumn{5}{|c|}{ Source Characteristics } \\
\hline Location & Longit. $=5^{\circ} 26^{\prime} \mathrm{W}$ & Latit. $=36^{\circ} 10^{\prime} \mathrm{N}$ & Height $=50 \mathrm{~m}$ AGL \\
\hline Time & Start: 01:30 GMT, 30 May & Stop: 02:00 GMT, 30 May \\
\hline Properties & PARTCULATE & Density $=1880 \mathrm{~kg} \mathrm{~m}^{-3}$ & Half-life $=30.17 \mathrm{yr}$ \\
\hline (Cesium-137) & Size distribution: & $0.1 \mu \mathrm{m} \leq d_{p} \leq 1.0 \mu \mathrm{m}$ & $0.5 \mu \mathrm{m}$ mean $d_{p}$ \\
\hline \multicolumn{4}{|c|}{ Particle Mass Characteristics } \\
\hline Release rate & 600 per timestep & 36000 particles (total) \\
\hline Total mass & $80 \mathrm{Ci}(0.8 \mathrm{~g})$ over 30 minutes & \\
\hline Initial mass & $0.00222 \mathrm{Ci}\left(2.2 \times 10^{-5} \mathrm{~g}\right)($ per particle) & \\
\hline \multicolumn{4}{|c|}{ Computation Characteristics } \\
\hline Grid cell (horiz) & $25 \mathrm{~km}$ & Timestep & $30 \mathrm{sec}$ \\
\hline
\end{tabular}




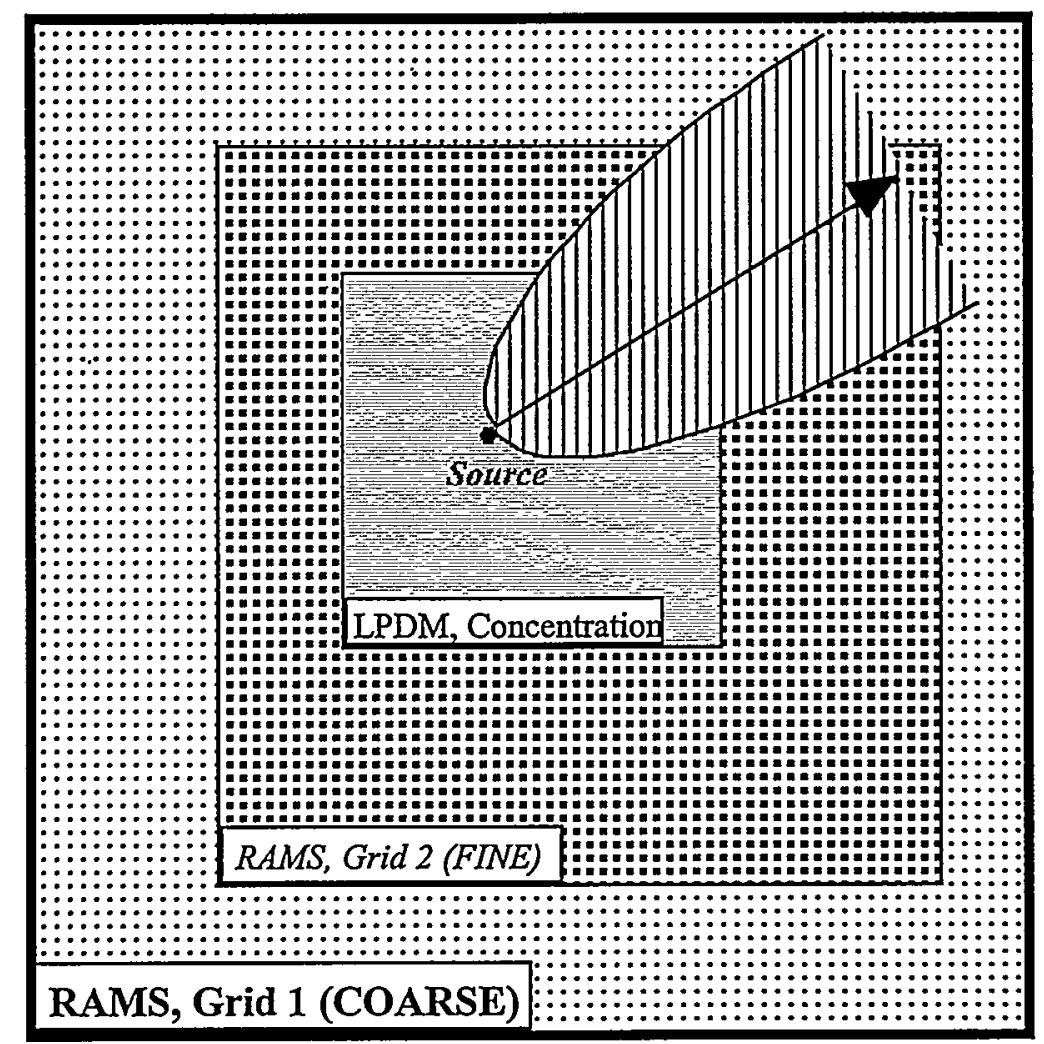

Figure 1: Schematic representation of different grids used in RAMS and LPDM. A two-grid RAMS simulation domain is depicted, with an LPDM concentration grid located within the finer RAMS grid. A generic plume as released from a source within the LPDM concentration grid is shown to impact all of the grids. 


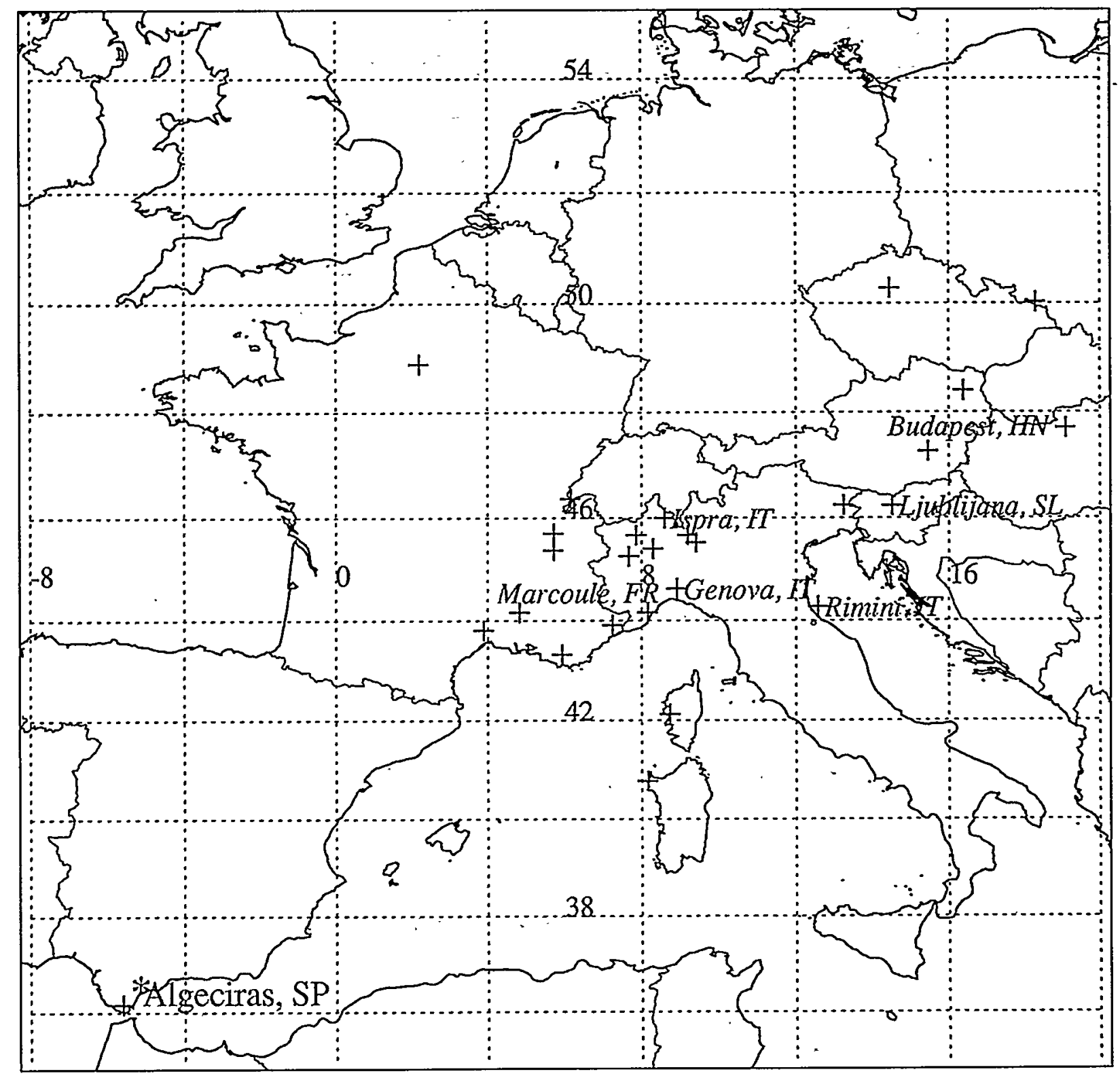

Figure 2: Grid domain utilized in the Algeciras, Spain release simulation. Locations of some of the measurement sites are denoted with ' + ', along with several city names. Dotted lines and numbers indicate latitude $\left(2^{\circ}\right.$ increments) and longitude ( $4^{\circ}$ increments). 
(a)

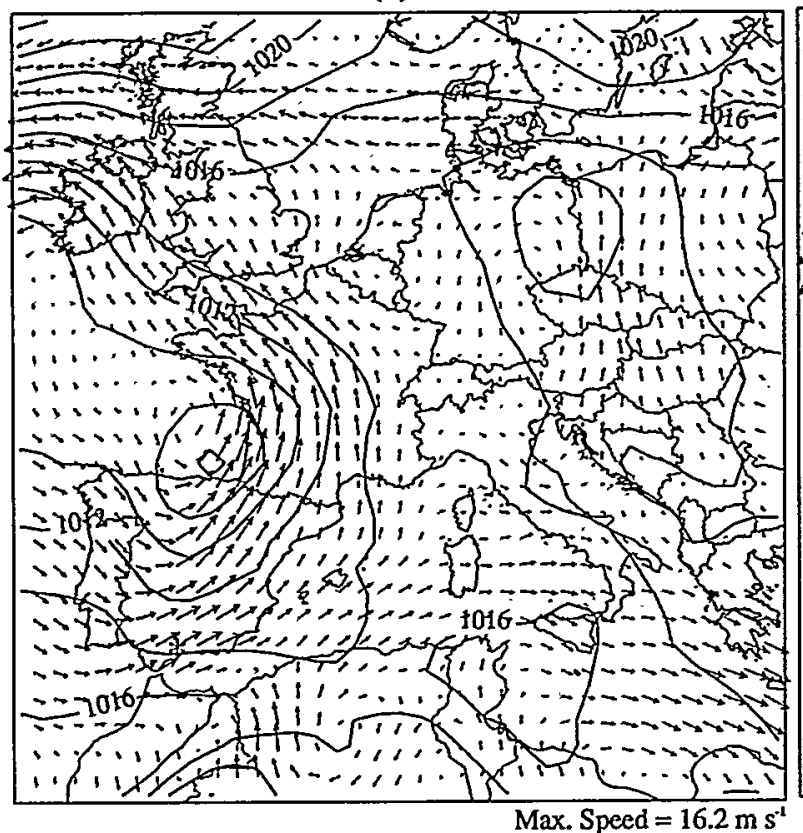

(c)

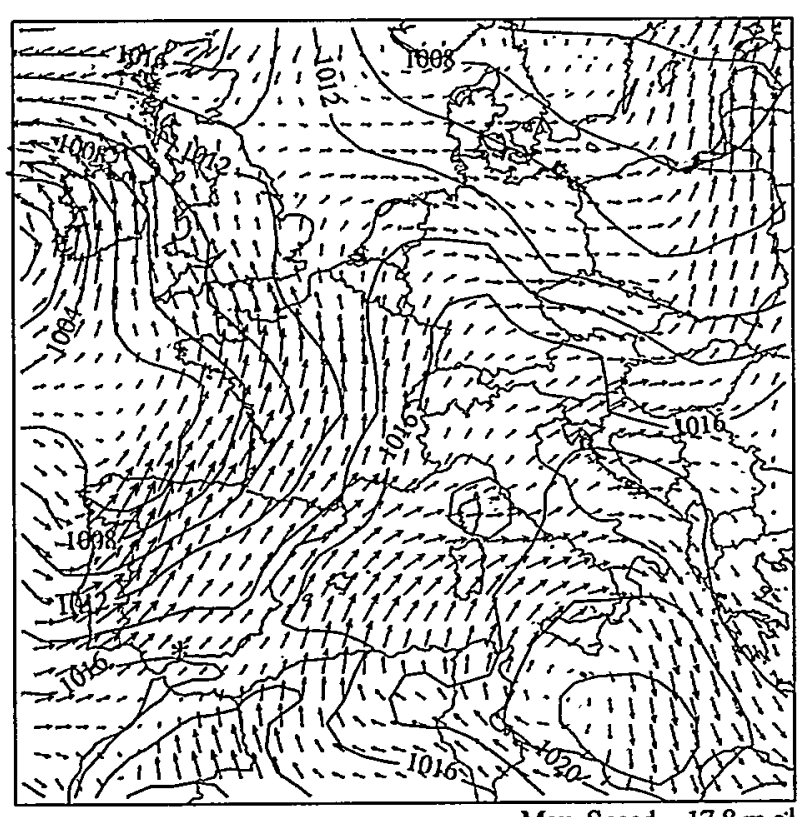

Max. Speed $=17.8 \mathrm{~m} \mathrm{~s}^{-1}$ (b)

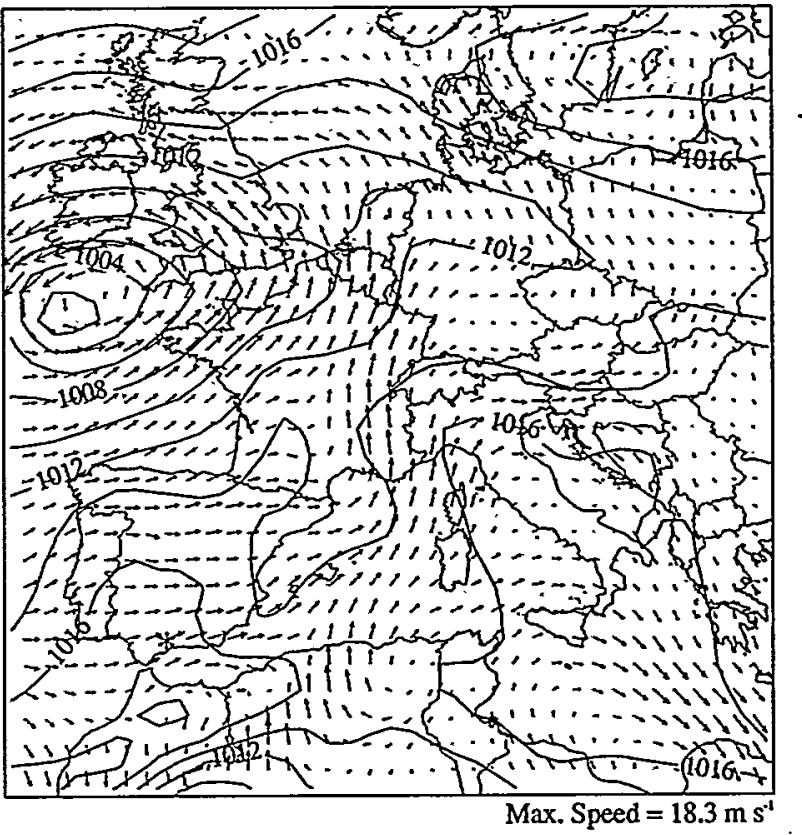

(d)

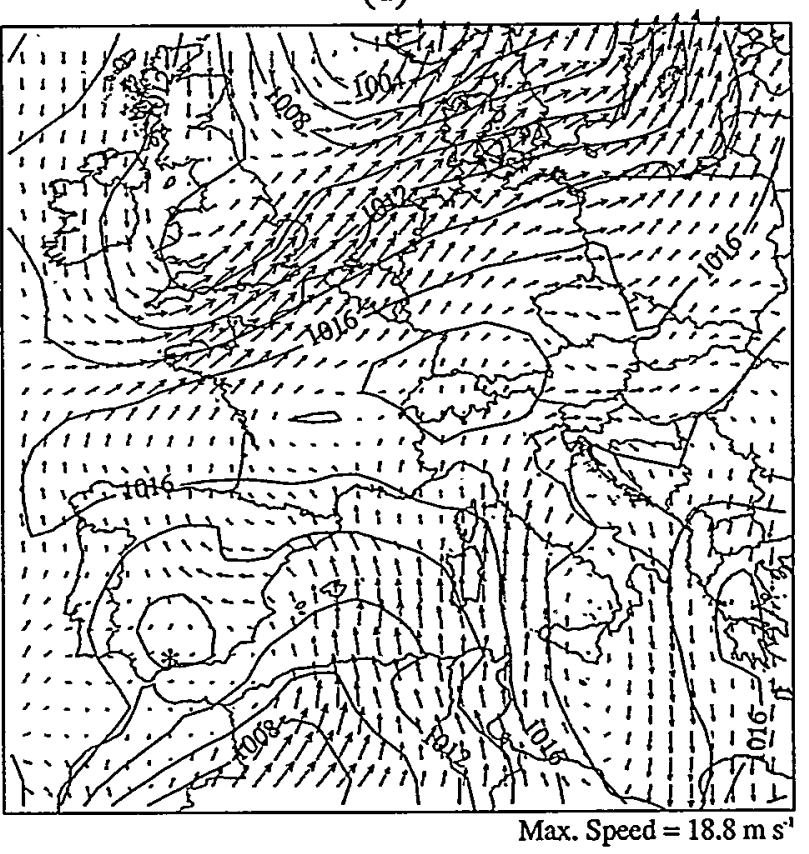

Figure 3: Synoptic surface conditions using MRF (Aviation) analyses at $1000 \mathrm{mbar}$ at (a) 00 GMT, 30 May 1998, (b) 00 GMT, 31 May, (c) 12 GMT, 01 June, (d) 12 GMT, 03 June.

Contours of sea-level pressure (mbar) are shown as solid lines, while arrows represent wind speed and direction. The maximum wind speed indicates the length of the longest arrows. The source location is given by '*'). 
(a)

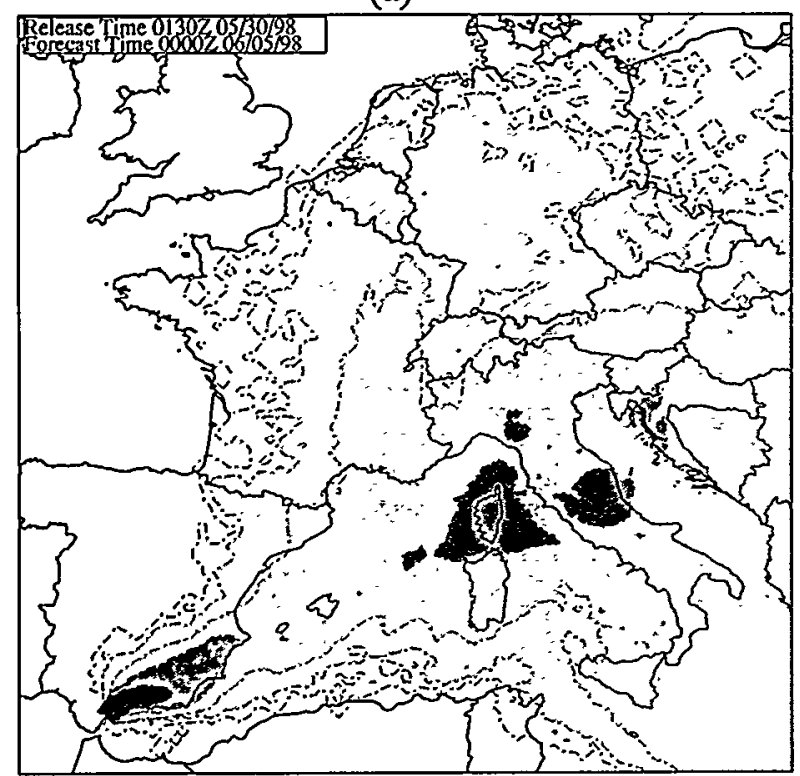

(b)

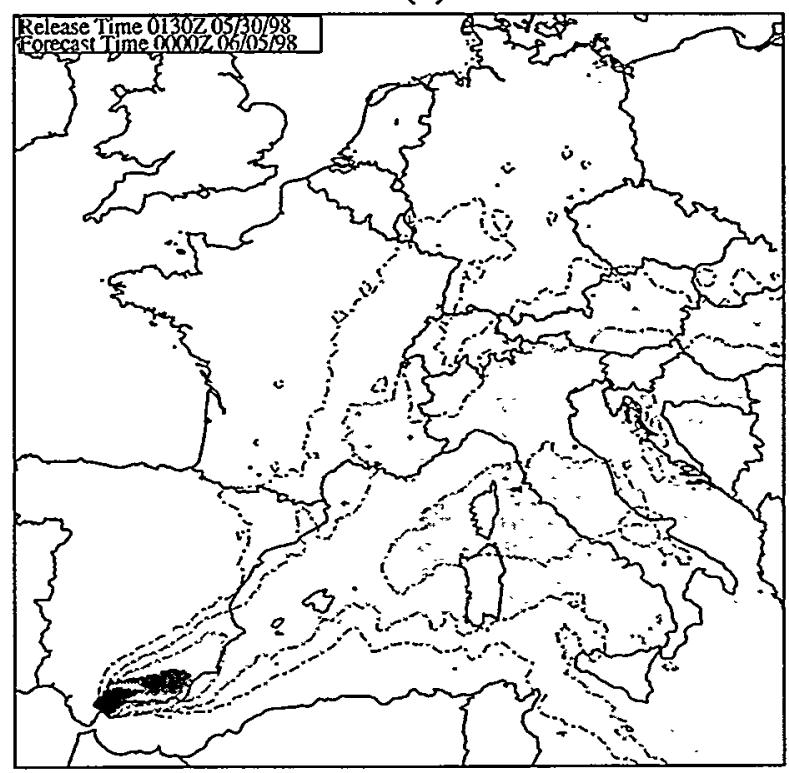

(c)

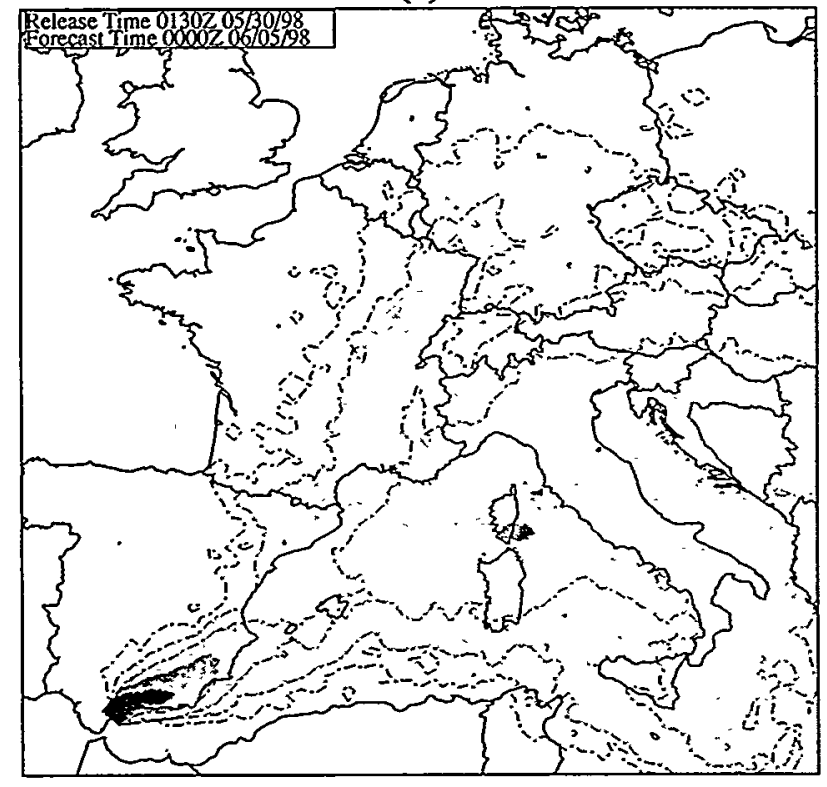

Figure 4: Integrated airborne concentration near the surface after 6 days. Contour values decrease in orders of magnitude from $10^{6} \mu \mathrm{Bq} \mathrm{m}^{-3}$ (darkest shading) to $10^{2} \mu \mathrm{Bq} \mathrm{m}{ }^{-3}$ (lightest shading). (a) No deposition, (b) constant deposition, (c) variable deposition. 
(a)

$\therefore$

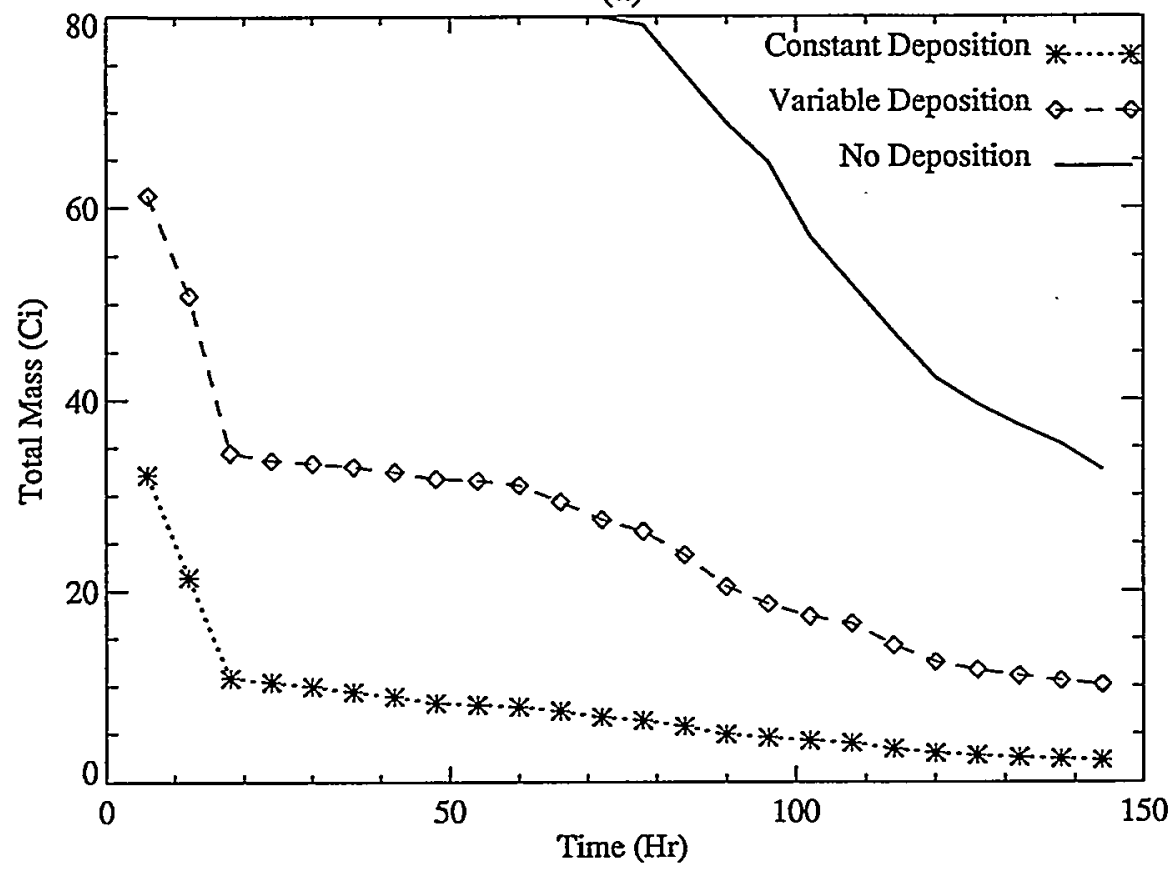

(b)

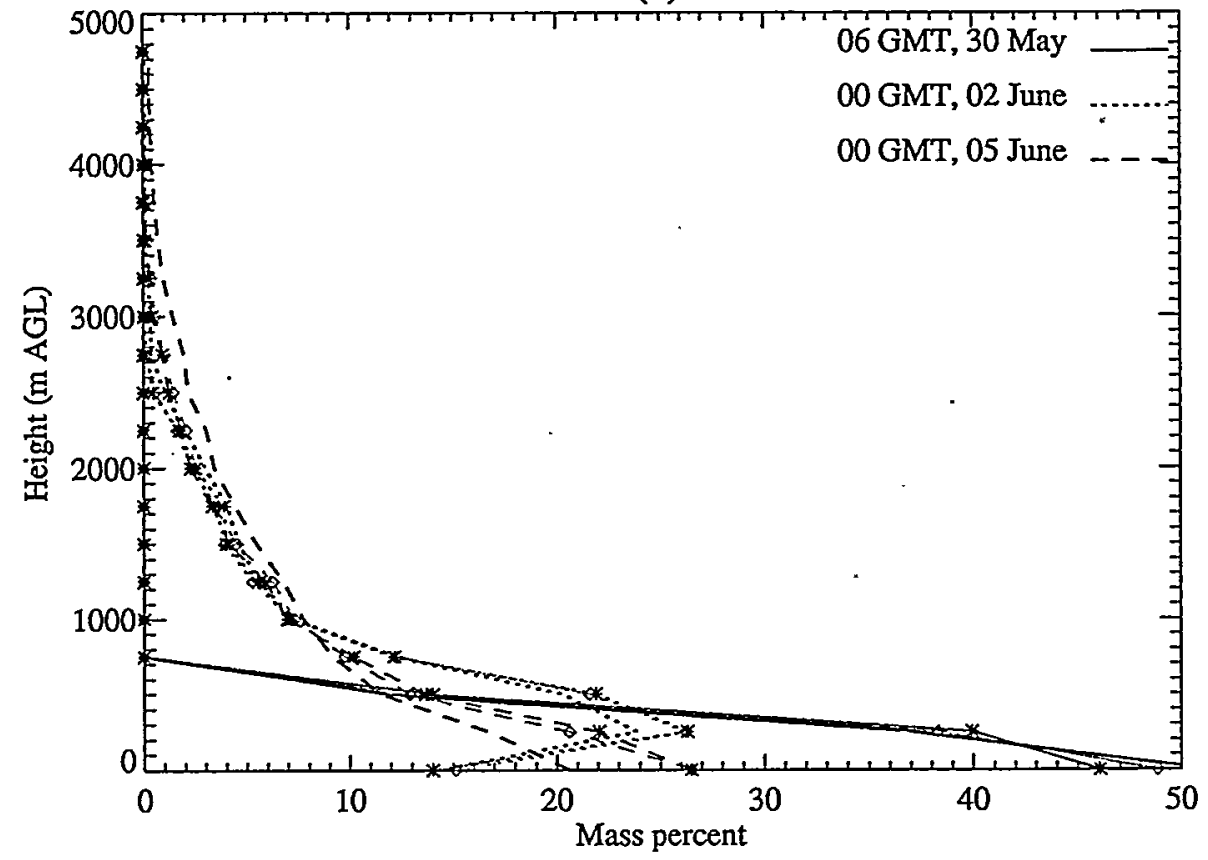

Figure 5: (a) Total mass (Ci) as a function of time since the start of the LPDM simulation at 6-hr intervals for constant deposition (dotted line, asterisks), variable deposition (dashed line, diamonds), and no deposition (solid line). The total mass released is $80 \mathrm{Ci}(0.8 \mathrm{~g})$. (b) Percentage of mass by height (at 250-m intervals) at three different times for each șimulation. Simulation case denoted by markers as in part (a). Linestyle differs for differing times. 

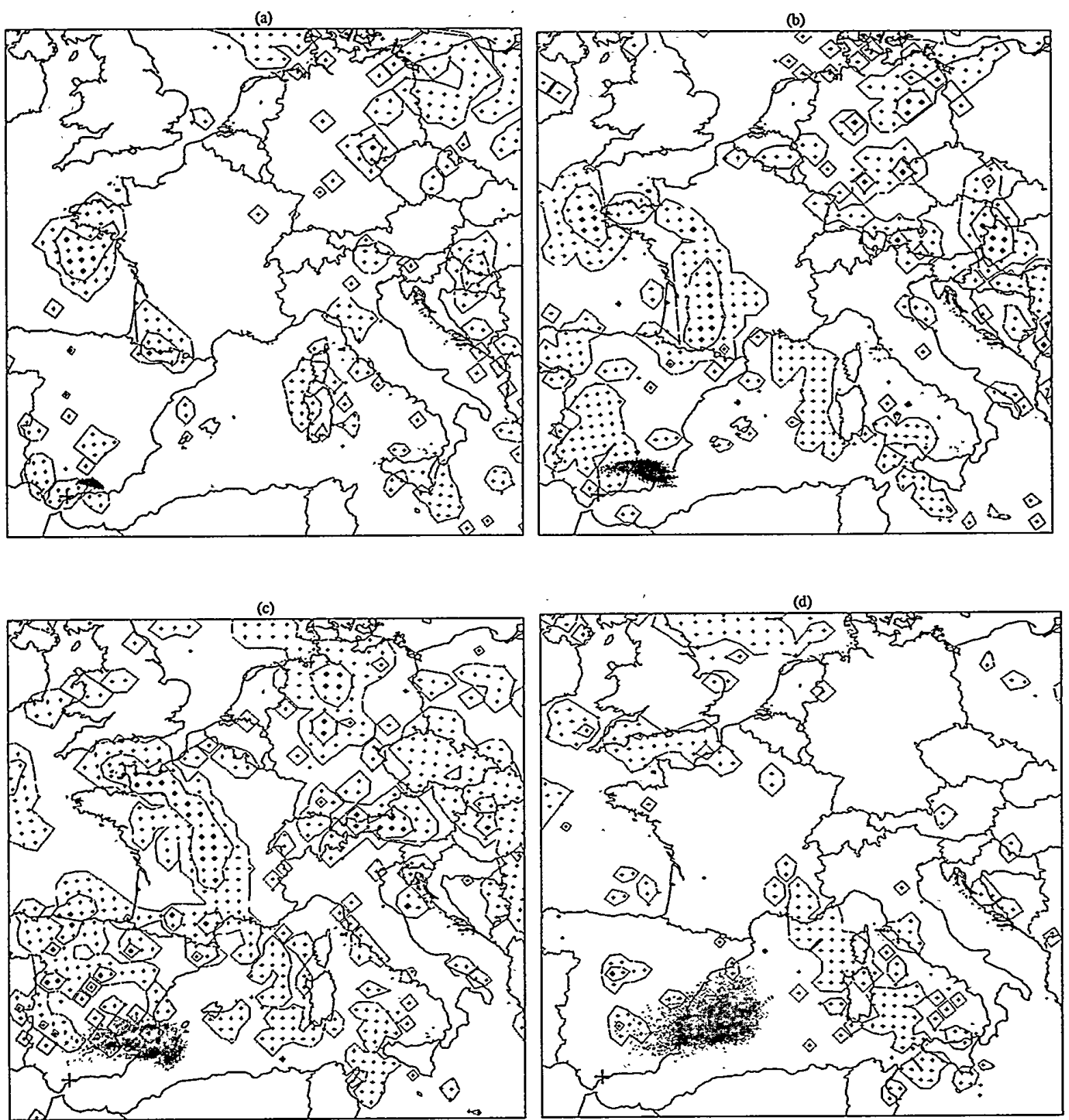

Figure 6: Plan view of all LPDM particles and simulated rain-mixing ratios contours in the lowest $150 \mathrm{~m}$ from RAMS. The smallest contour interval is $10^{-6}\left[\mathrm{gm}_{\mathrm{H} 2 \mathrm{O}} \mathrm{gm}_{\mathrm{Air}}{ }^{-1}\right]$, with individual RAMS grid locations indicated by a ' + '. The inner contour intervals $10^{-3}$ [gm, $\mathrm{gm}_{2}$ $\left.\mathrm{gm}_{\text {,Air }}{ }^{-1}\right]$ are marked also with diamonds. Each frame represents a different time: (a) $06 \mathrm{GMT}, 30$ May 1998, (b) 12 GMT, 30 May, (c) 18 GMT, 30 May, and (d) 00 GMT, 31 May. 
(a) Marcoule, FRANCE

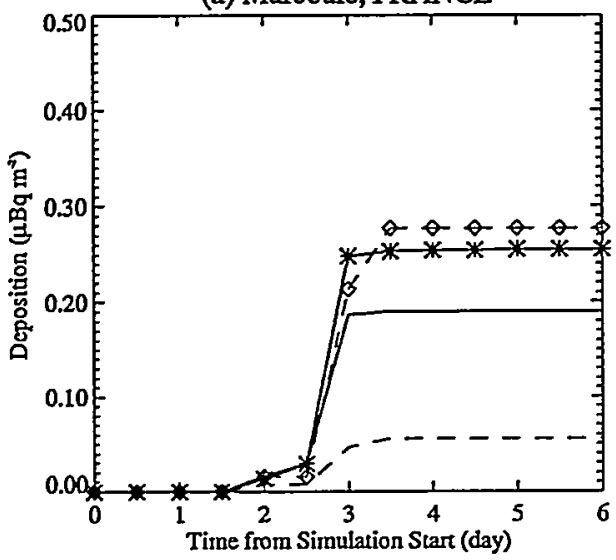

(c) Ispra, ITALY

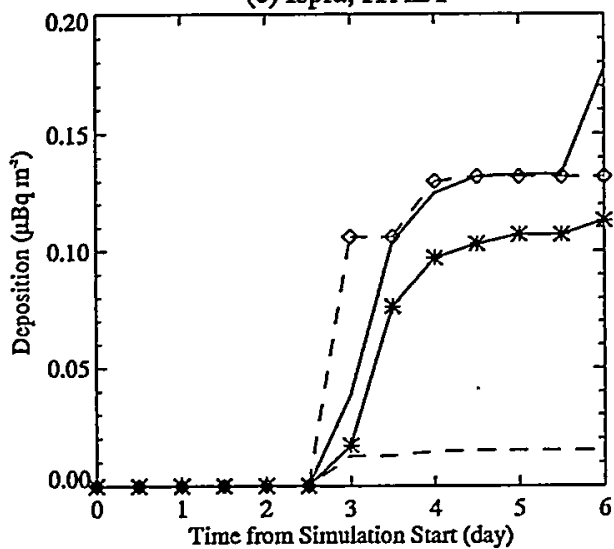

(e) Ljublijana, SLOVENIA

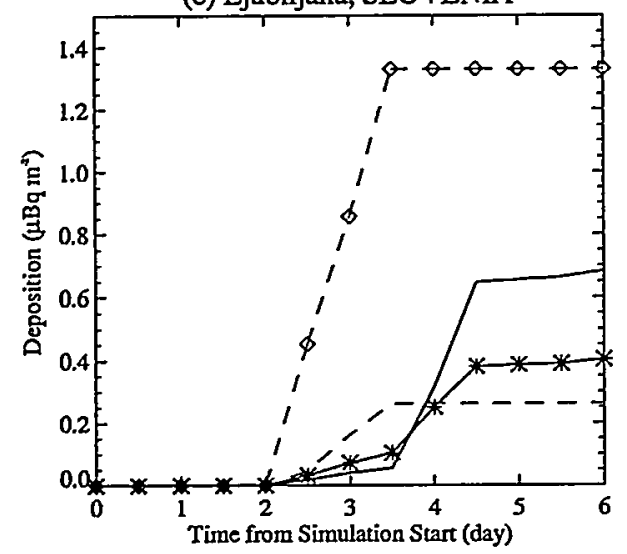

(b) Genova, ITALY

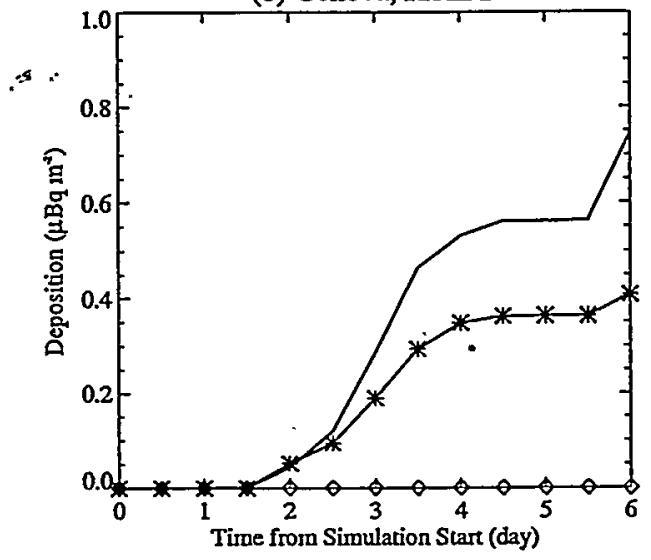

(d) Rimini, ITALY

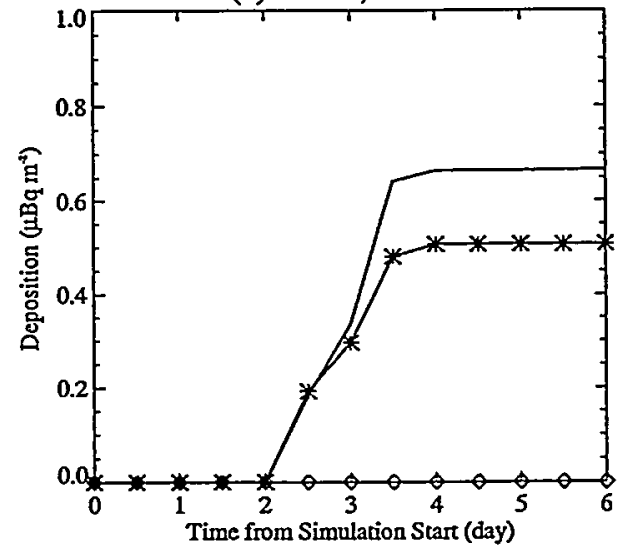

(f) Budapest, HUNGARY

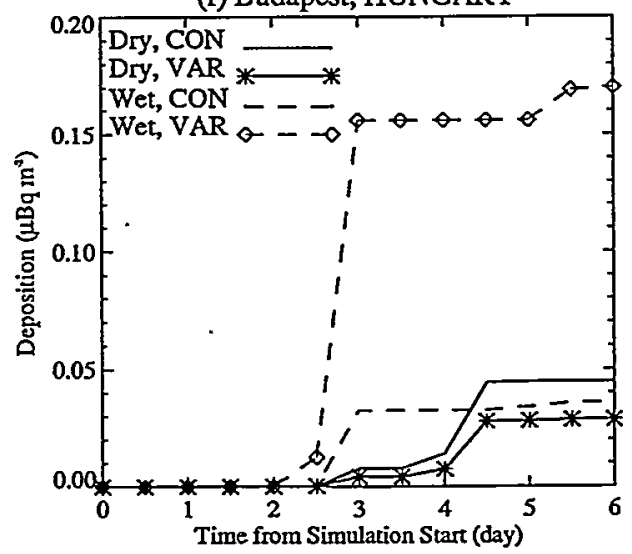

Figure 7: Comparison of cumulative dry and wet deposition $\left(\mu \mathrm{Bq} \mathrm{m}{ }^{-2}\right)$ as simulated for the variable deposition case (VAR) and the constant deposition case (CON). Dry deposition values are given with bold solid lines, while the wet deposition values are given with dashed lines. Markers denote the use of variable deposition. Results are shown for six different cities in which measurements were recorded (see Fig. 2 for relative locations). Note the different vertical scales for different locations. 

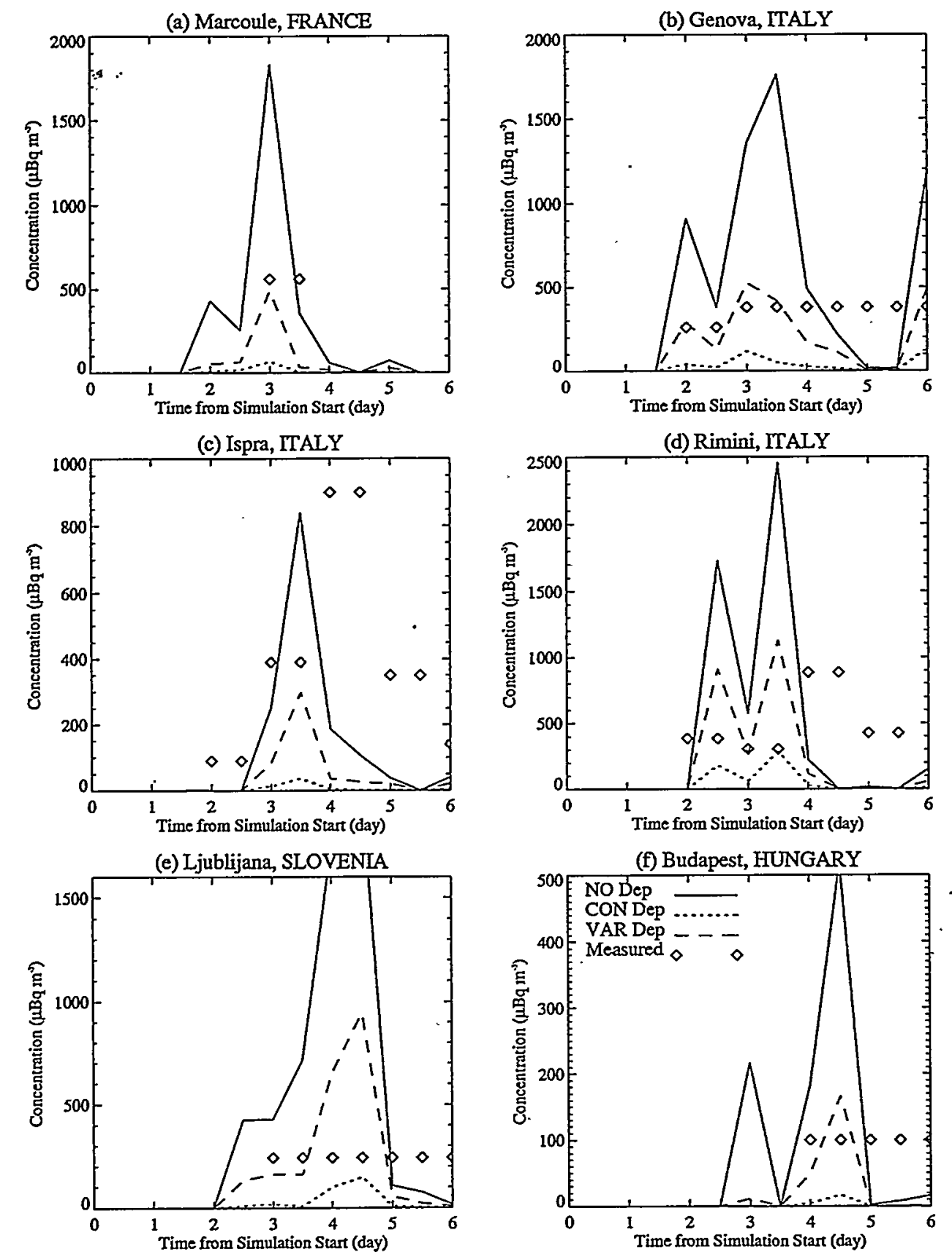

Figure 8: Comparison of measured averaged airborne surface concentration $\left(\mu \mathrm{Bq} \mathrm{m} \mathrm{m}^{-3}\right)$ and simulated averaged surface concentrations over the same time period and for the same locations as in Fig. 7. The solid line indicates no deposition in the LPDM simulation, while the dotted line shows constant deposition calculations. The dashed line indicates variable deposition, while the diamonds represent measured quantities. Simulated averages are for a 12 -hr period, while measured values are for 1 to 5 -day periods. Note the differing vertical scales for different locations. 


\section{APPENDIX A: Resistance Calculations in Variable Dry Deposition}

From a computational standpoint, several items from the mesoscale model (RAMS) are needed in the calculation of dry deposition velocity within LPDM. These include:

$u_{L}^{*}, u_{W}^{*}:$ surface flux (friction) wind speed over land, water $\left[\mathrm{m} \mathrm{s}^{-1}\right]$

$\theta_{L}^{*}, \theta_{W}^{*}:$ surface flux (friction) temperature over land, water [K]

$R_{S W:} \quad$ short-wave radiation $\left[\mathrm{W} \mathrm{m}^{-2}\right]$.

The surface flux values over a particular RAMS grid cell are dependent on the land percentage, $P_{L}$, (the percent land coverage of a grid cell)

$$
\begin{aligned}
& u^{*}=u_{L}^{*}\left(P_{L} / 100\right)+u_{W}^{*}\left(1-P_{L} / 100\right) \\
& \theta^{*}=\theta_{L}^{*}\left(P_{L} / 100\right)+\theta_{W}^{*}\left(1-P_{L} / 100\right)
\end{aligned}
$$

The roughness length for a grid cell, $z_{0}$, is calculated in a similar manner, where the value over water is calculated using Clarke (1970),

$$
z_{0, W}=\frac{0.032\left(u^{*}\right)^{2}}{g}, z_{0, W} \geq 1.5 \times 10^{-5} \mathrm{~m}
$$

The roughness length over land, $z_{0, L}$, is dependent on the surface vegetation type, leading to the expression for the overall roughness length:

$$
z_{0}=z_{0, L}\left(P_{L} / 100\right)+z_{0, W}\left(1-P_{L} / 100\right)
$$

\section{Aerodynamic Resistance $\left(r_{A}\right)$}

The aerodynamic resistance uses surface-layer similarity theory (Businger et al. 1971). For pollutants existing at height $z$ above the ground,

$$
r_{A}=\frac{\ln \left(z / z_{0}\right)-\psi_{H}}{\kappa u^{*}}
$$

where the roughness length is given by $z_{0}, \kappa$ is von Karman's constant $(0.35)$, and $u^{*}$ is the surface friction velocity. The final term in the numerator, $\psi_{H}$, is a non-dimensional scalar profile function based on atmospheric properties. The formulation discussed in Mahrer and Pielke (1977) is used here: 


$$
\psi_{H}=\left\{\begin{array}{cc}
2 \ln \left[\left(1+0.74 / \phi_{H}\right) / 2\right] & , z / L \leq 0 \\
-6.35 z / L & , z / L>0
\end{array}\right.
$$

The term $\phi_{H}$ is given as

$$
\phi_{H}=\left\{\begin{array}{cc}
0.74(1-9 z / L)^{-\frac{1}{2}} & ; z / L \leq 0 \\
0.74+4.7 z / L & , z / L>0
\end{array}\right.
$$

with the Monin-Obukhov length, $\bar{L}$, written as:

$$
L=\frac{\theta\left(u^{*}\right)^{2}}{\kappa g \theta^{*}}
$$

where $\theta$ is the potential temperature near the surface and $\theta^{*}$ is the surface friction temperature. Note that this formulation applies to both gaseous and particulate $\left(r_{A, p}\right)$ releases.

\section{Sublayer Resistance $\left(r_{B}\right)$}

The sublayer resistance is due to molecular diffusion in the thin sublayer near the surface. It increases with decreasing diffusivity and increasing surface roughness. This implies that for smaller particles, the resistance decreases, since the Brownian diffusion coefficient increases (Hinds 1982). Since diffusivity in gases is larger than particulates, values of $r_{B}$ for gases is larger than that of particulates. A simplified form relating this resistance to micrometeorological variables for gaseous releases is used (Wesely and Hicks 1977)

$$
r_{B, g}=\frac{2.6}{\kappa u^{*}}
$$

while for particulate releases, the parameterization utilized is (Seinfeld 1986)

$$
r_{B, p}=\frac{1}{u^{*}\left(S c^{-2 / 3}+10^{-3 / S t}\right)}
$$

The dimensionless parameters used in this relation are the Schmidt $(S c)$ and Stokes $(S t)$ numbers. The Schmidt number, relating fluid viscosity and diffusivity, is expressed 


$$
S c=\frac{\mu_{a i r}}{\rho_{a i r} D}
$$

with the Brownian diffusivity, $D$, written (Hinds 1982)

$$
D=\frac{k_{B} T C u}{3 \pi \mu d_{p}}
$$

where $T$ represents the surface temperature and $k_{B}=1.38 \times 10^{-23}\left[\mathrm{~kg} \mathrm{~m}^{2} \mathrm{~s}^{-2} \mathrm{~K}^{-1}\right]$ is Boltzmann's constant. The Stokes number is a measure of the probability of particle collisions and is given as

$$
S t=\frac{v_{g}\left(u^{*}\right)^{2} \rho_{a i r}}{g \mu_{a i r}} .
$$

\section{Surface Resistance $\left(r_{C}\right)$}

Finally, surface resistance ( $r_{C, g}$, gaseous releases only) is expressed using tabular information from Walcek et al. (1986) for sulfur dioxide $\left(\mathrm{SO}_{2}\right)$, sulfate, and nitric acid $\left(\mathrm{HNO}_{3}\right)$ based on regional landuse categories and incoming shortwave radiation. Values have been modified as in Arritt et al. (1988) and configured with the BATS vegetation categories used in RAMS (Dickinson et al. 1986). It is recognized that use of these values for all gaseous releases is a weakness in the paramaterization. However, it is also quite likely that uncertainty due to other factors (such as meteorology) will outweigh the errors introduced by this assumption.

Since the surface resistance is known to depend on plant stomatal activity, solar insolation and precipitation-cover on the vegetation are considered in Walcek et al.'s (1986) analysis. Thus, the first step accounts for incoming solar radiation $\left[\mathrm{W} \mathrm{m}^{-2}\right]$ at the surface of the model using

$$
r_{C, D R Y}=\left\{\begin{array}{cc}
r_{C, M A X} & , R_{S W}=0 \\
r_{C, M I N}+\left(r_{C, M A X}+r_{C, M I N}\right)\left[1-\left(\frac{R_{S W}}{400}\right)^{1 / 3}\right] & , 0<R_{S W}<400 . \\
r_{C, M I N} & , 400 \leq R_{S W}
\end{array}\right.
$$

Dew covered surfaces are also important in stomatal activity. In the modified version of Arritt et al. (1988), dew coverage is assumed using a threshold relative humidity, $R H_{t}$. The formulation is used here (assuming $R H_{t}=90 \%$ ), with a surface resistance expressed as 


$$
r_{C, g}=\left\{\begin{array}{cc}
r_{C, D R Y} & , R H<R H_{t} \\
r_{C, W E T}+\left(r_{C, D R Y}+r_{C, W E T}\right)\left(\frac{1-R H}{1-R H_{t}}\right) & , R H_{t} \leq R H<1 . \\
r_{C, W E T} & , 1 \leq R H
\end{array}\right.
$$

The values for $r_{C, M I N}, r_{C, M A X}$, and $r_{C, W E T}$ differ according to the vegetation cover for a particular grid cell. Values used are adopted from Arritt et al. (1988) and shown in Table A.1.

Table A.1: Canopy Resistance Values $\left(\mathrm{s} \mathrm{m}^{-1}\right)$ as a Function of Vegetation Type.

\begin{tabular}{|l|ccc|l|ccc|}
\hline Vegetation Category & $r_{C, M I N}$ & $\dot{r}_{C, M A X}$ & $r_{C, W E T}$ & Vegetation Category & $r_{C, M I N}$ & $r_{C, M A X}$ & $r_{C, W E T}$ \\
\hline 1: Crop/mixed farming & 100 & 500 & 10 & 10: Irrigated crop & 70 & 400 & 10 \\
2: Short grass & 100 & 400 & 50 & 11: Semi-desert & 1000 & 1000 & 500 \\
3: Evergr. needleleaf tree & 150 & 1200 & 50 & 12: Ice cap/glacier & 0 & 0 & 0 \\
4: Decid. needleleaf tree & 90 & 1200 & 50 & 13: Bog or marsh & 50 & 100 & 10 \\
5: Decid. broadleaf tree & 90 & 1200 & 50 & 14: Inland water & 0 & 0 & 0 \\
6: Evergr. broadleaf tree & 150 & 1200 & 50 & 15: Ocean & 0 & 0 & 0 \\
7: Tall grass & 100 & 400 & 50 & 16: Evergreen shrub & 100 & 400 & 50 \\
8: Desert & 1000 & 1000 & 500 & 17: Deciduous shrub & 100 & 400 & 50 \\
9: Tundra & 1000 & 1000 & 500 & 18: Mixed woodland & 90 & 1200 & 50 \\
\hline
\end{tabular}




\section{APPENDIX B: Revision to the Input File for LPDM}

The following parameters have been added to the LPDM input list:

IDEPO: Deposition flag

$0 \rightarrow$ No deposition.

$1 \rightarrow$ SIMPLE wet and dry deposition. This implies constant dry deposition velocity and scavenging coefficient.

$2 \rightarrow$ COMPLEX wet and dry deposition. This implies using variable dry deposition velocity based on meteorology, release type, and surface conditions as discussed in Appendix A. The wet deposition varies according to the precipitation rate, which is calculated from the rain-mixing ratio supplied from RAMS.

VDEP: $\quad$ Constant deposition velocity $\left[\mathrm{m} \mathrm{s}^{-1}\right]$.

This is used for simple dry deposition calculations $(I D E P O=1)$.

GAMWET: Constant washout coefficient $\left[\mathrm{s}^{-1}\right]$.

This is used for simple wet deposition calculations $(I D E P O=1)$.

IGAS_PAR: Flag for determining if release is gaseous or particulate in nature.

This is only used if deposition is turned on in the simulation.

$0 \rightarrow$ Gaseous release

$1 \rightarrow$ Particulate release

DENS: Density $\left[\mathrm{kg} \mathrm{m}^{-3}\right]$ of the effluent.

For particulate releases, this is important in calculations pertaining to the dry deposition velocity and for determining the gravitational settling velocity. Typical values of density for particulate emissions are 1000 to $3000\left[\mathrm{~kg} \mathrm{~m}^{-3}\right]$ (Hinds 1982). For gaseous releases, if gravitational settling is desired (ILPFALL $=1$ ), then the particle density used to define the settling velocity is generally 3 orders of magnitude smaller (i.e. $\sim 1\left[\mathrm{~kg} \mathrm{~m}^{-3}\right]$ ). The density is only used when the particles are initially emitted into the simulation domain. 


\section{WESTINGHOUSE SAVANNAH RIVER COMPANY}

Report WSRC-TR-99-00409

\section{DISTRIBUTION}

\section{SAVANNAH RIVER SITE}

P. Deason, 773-A
A. L. Boni, 773-A
R. P. Addis, 773-A
A. J. Garrett, 773-A
D. P. Griggs, 773-A
C. H. Hunter, 773-A
R. J. Kurzeja, 773-A
M. J. Parker, 735-7-A
B. L. O'Steen, 773-A
A. H. Weber, 773-A
R. L. Buckley, 773-A
SRTC Records(4), 773-52A
ATG Records(5), 773-A 